\title{
New Chorological Data for the Italian Vascular Flora
}

\author{
Leonardo Rosati ${ }^{1, *} \mathbb{\infty}$, Simonetta Fascetti ${ }^{1} \odot$, Vito Antonio Romano ${ }^{1}$, Giovanna Potenza ${ }^{1}$, \\ Maria Rita Lapenna ${ }^{1}$, Antonio Capano ${ }^{1}$, Pietro Nicoletti ${ }^{1}$, Emmanuele Farris ${ }^{2}{ }^{\mathbb{D}}$, \\ Peter James de Lange ${ }^{3}\left(\mathbb{D}\right.$, Eva Del Vico ${ }^{4}$, Laura Facioni ${ }^{4}$, Emanuele Fanfarillo ${ }^{4}$, Edda Lattanzi ${ }^{4}$, \\ Ana Cano-Ortiz ${ }^{5}$, Michela Marignani ${ }^{6}\left(\mathbb{D}\right.$, Maria Caterina Fogu ${ }^{6}$, Erika Bazzato ${ }^{6} \mathbb{D}^{D}$, Erik Lallai ${ }^{6}$, \\ Valentina Lucia Astrid Laface ${ }^{7}$, Carmelo Maria Musarella ${ }^{7}$ D, Giovanni Spampinato ${ }^{7}$, \\ Giacomo Mei ${ }^{8}$, Giuseppe Misano ${ }^{1}$, Giovanni Salerno ${ }^{9}$, Assunta Esposito ${ }^{10} \mathbb{D}$ and \\ Adriano Stinca 10 \\ 1 School of Agriculture, Forestry, Food and Environment, University of Basilicata, 85100 Potenza, Italy \\ Department of Chemistry and Pharmacy, University of Sassari, 07100 Sassari, Italy \\ School of Environmental and Animal Sciences, Unitec Institute of Technology, 1025 Auckland, New Zealand \\ Department of Environmental Biology, Sapienza University of Rome, 00185 Rome, Italy \\ Department of Animal and Plant Biology and Ecology, Section of Botany, University of Jaén, \\ Campus Universitario Las Lagunillas, 23071 Jaén, Spain \\ 6 Department of Life and Environmental Sciences, University of Cagliari, 09123 Cagliari, Italy \\ 7 AGRARIA Department, Mediterranea University of Reggio Calabria, 89122 Reggio Calabria, Italy \\ 8 Department of Agricultural, Food and Environmental Sciences, Marche Polytechnic University, \\ 60131 Ancona, Italy \\ 9 Department of Science, University of Roma Tre, 00146 Rome, Italy \\ 10 Department of Environmental, Biological and Pharmaceutical Sciences and Technologies, University of \\ Campania Luigi Vanvitelli, 81100 Caserta, Italy \\ * Correspondence: leonardo.rosati@unibas.it
}

Received: 5 December 2019; Accepted: 2 January 2020; Published: 5 January 2020

\begin{abstract}
Despite the importance for scientific and conservation purposes, the knowledge of the Italian territory is far from exhaustive. New chorological data for 87 vascular taxa regarding the central-southern part of Italy and its two main islands (Sicilia and Sardegna) are presented. Among these taxa, Epilobium nummularifolium, Metrosideros excelsa, and Salvinia minima are recorded as casual aliens for the first time in Europe (excluding Azores and Madeira for M. excelsa), while Cyclamen balearicum and Polygala rupestris are reported for the first time and confirmed for Italian native flora, respectively. Furthermore, several taxa are new or confirmed at regional level. Finally, Lathyrus cirrhosus, Urginea fugax, and Linum tenuifolium are excluded from Italy, continental and peninsular Italy, and Sardegna, respectively.
\end{abstract}

Keywords: alien species; endemic plants; checklist; new floristic records; plant diversity

\section{Introduction}

Over the past 20 years, floristic studies of the central-southern Italian Peninsula have greatly improved our knowledge of the flora of this region [1-15] and some syntheses at the national scale [16-22] have been made available.

However, despite the importance for scientific and conservation purposes, our knowledge of the Italian territory is far from exhaustive. In particular, in some regions of Italy, knowledge about the vascular flora remains inadequate usually because the geographic distributions of many species are poorly understood resulting in gaps in our knowledge of their actual extent [23]. This is the so-called "Wallacean shortfall," that is considered one of the crucial sources of uncertainty in 
biodiversity inventories, limiting both biosystematic and ecological analyses of these [24,25] and resulting in some exceptional discoveries when critical gaps are surveyed, such as finding of a new taxon of Gymnospermium (Berberidaceae) in an unexplored mountain range between Basilicata and Campania [26,27]. Further biological invasions represent a major threat to biodiversity [28,29], particularly as new naturalizations of alien vascular plants are continuously happening and are usually poorly documented within regional flora treatments. This is particularly the case on Mediterranean islands [30]. As a consequence, it is important that frequent assessment of regional floras are undertaken, not only to monitor the established populations (indigenous and naturalized), but also to update the distribution data to enable early warning of declines in indigenous or endemic species, and to document new arrivals of invasive plants, as an aid to better manage the invasive ones, particularly those species included in the European list of EU concern [31].

In this paper we document new observations of plants for the central-southern Italian Peninsula and the two main insular regions (Figure 1). Our records include both native and alien non-cultivated species with a careful assessment of the status of naturalization for the latter. For each taxon, relevant information about ecology and distribution are also provided.

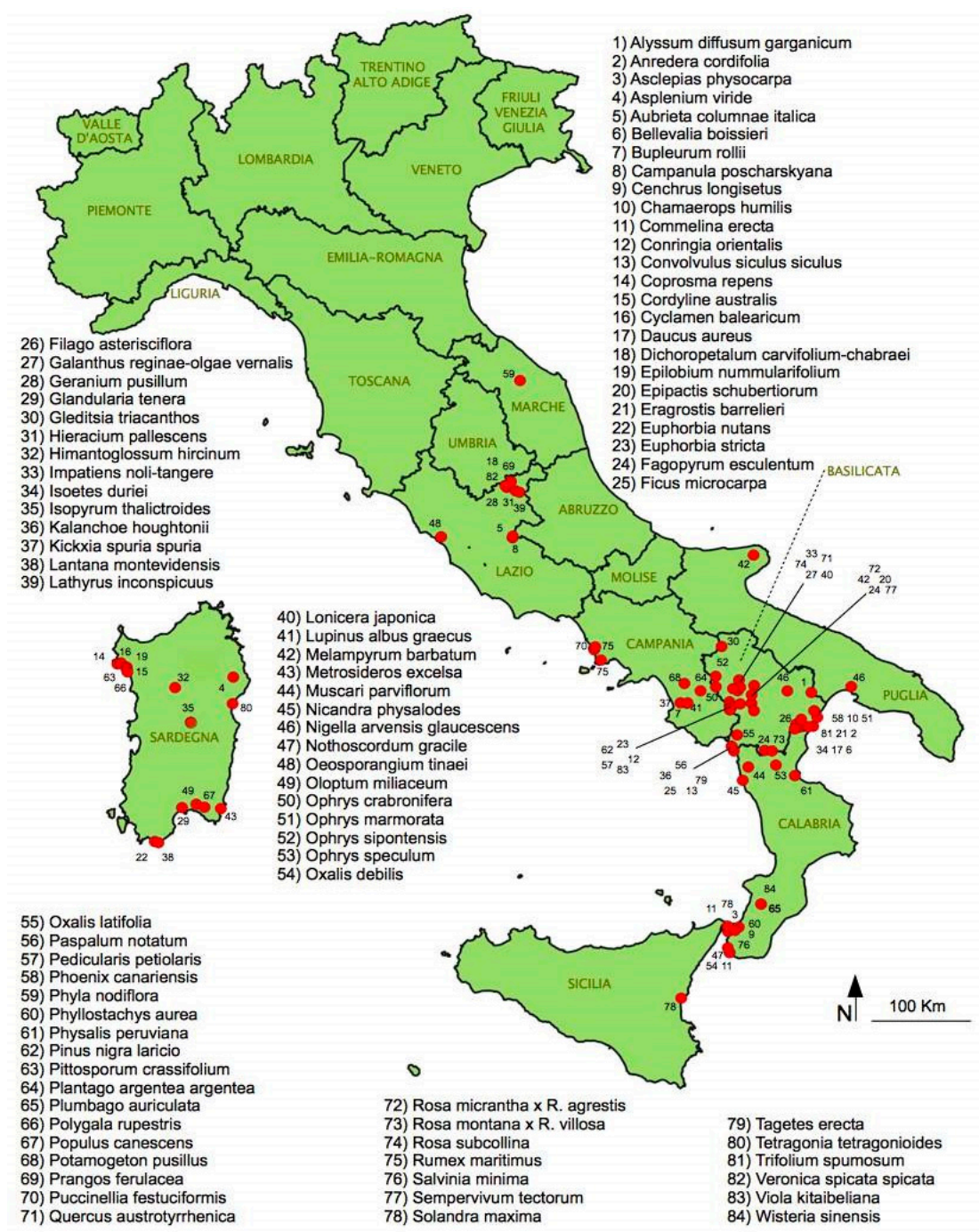

Figure 1. Research area with administrative Italian regions and locations of the new records of vascular plants reported in this study. We considered "continental Italy" the regions north to Toscana and Marche, "peninsular Italy" the other regions of Italian peninsula and "insular Italy" the Sardegna (Sardinia) and Sicilia (Sicily) regions. 


\section{Materials and Methods}

The floristic data are based on field investigation carried out by the authors in the study area, as well as on herbaria and literature surveys. The collected or examined materials are preserved in public (ANC, AK, HLUC, PORUN-Herb. Stinca, REGGIO, SS; acronyms according to Thiers [32]) or private herbaria. In the floristic list (Appendix A), taxa are arranged in alphabetical order. Nomenclature, taxa delimitation, and notes on the regional distribution follow the recent checklists of the Italian vascular flora [16,17] and their updates [33-40]. Nomenclature of the species that had not been previously reported from Italy and of Populus $\times$ canescens follows World Flora Online [41]. The taxa recorded in this paper were identified using Flora Europaea [42-46], Flora d'Italia [18-21,47], and some monographic works cited in the species' note listed in Appendix A.

For each species the following information is provided: basionym and most relevant synonyms; plant family; life form, attributed on the basis of field observations using the categories of Flora d'Italia [47]; native range; period of introduction (archaeophyte or neophyte); data report in the study area; current invasiveness status for each region, assessed by population monitoring over time according to the terminology of Pyšek et al. [48]; date and discovery localities with details on the location (municipality, administrative province), habitat, altitude, decimal degrees geographic coordinates (datum WGS84); collector(s) (legit), author(s) of the identification (determinavit) and, eventually, the identity confirmation (confirmavit); herbarium where specimen is kept; additional notes. Species not documented with a herbarium specimen are shown in Figure 2.
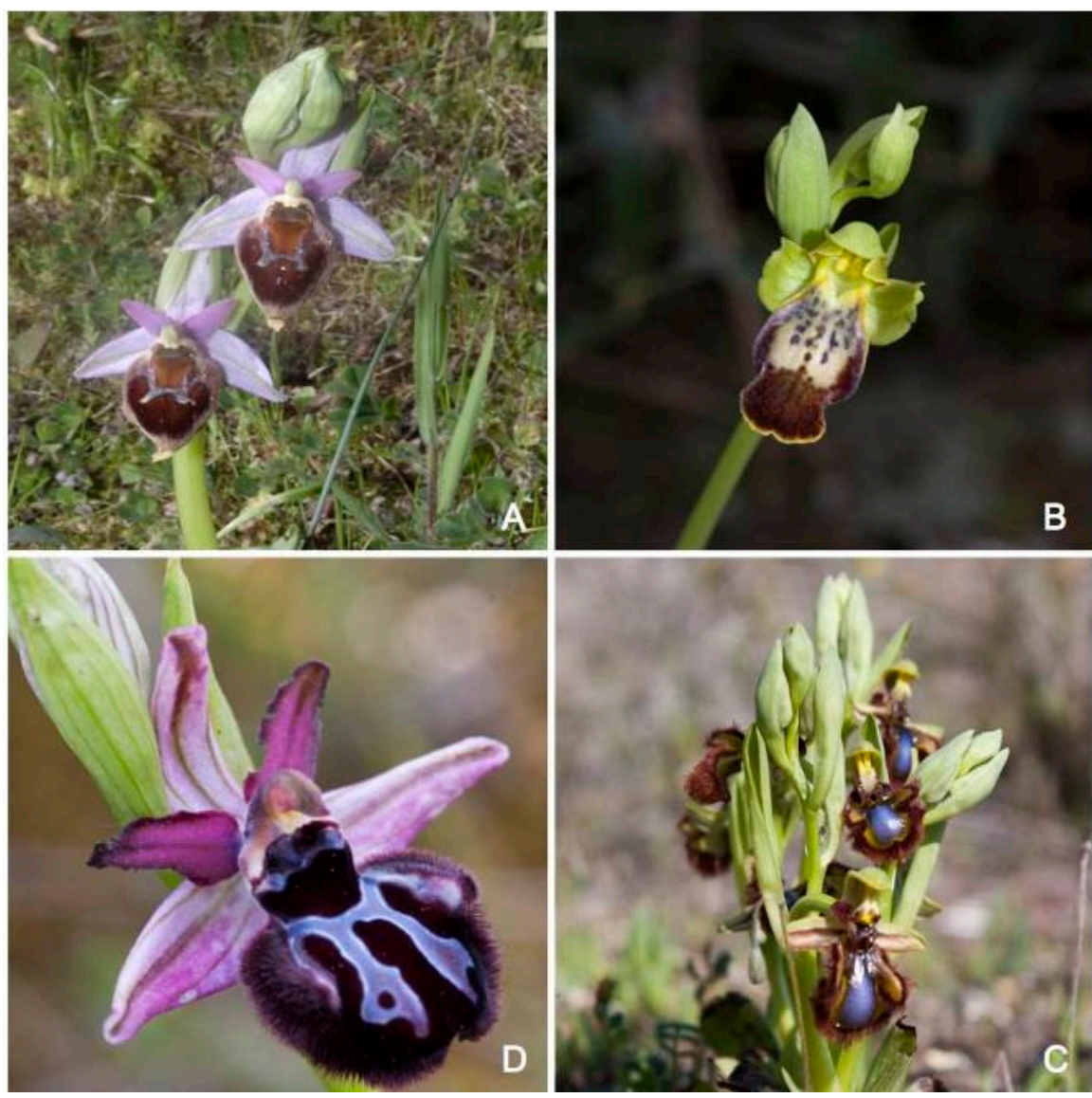

Figure 2. Species not documented by herbarium specimens in Appendix A: (A) Ophrys crabronifera, (B) O. marmorata, (C) O. speculum, (D) O. sipontensis. 


\section{Results}

Two native and four alien species are recorded for the first time in Italy; among the aliens, three species deserve more attention since they are new for Europe. Overall, 87 taxa of floristic interest for the Italian flora are herein reported, 50 are native and 37 represent alien taxa. Among the native plants seven are endemic taxa of the Italian territory.

\subsection{Native taxa}

Cyclamen balearicum and Polygala rupestris discovered in Sardegna are recorded for the first time in Italy, while Euphorbia stricta found in Basilicata is recorded as new for peninsular Italy (i.e., the regions south to Toscana and Marche, Sicilia and Sardegna excluded). Lathyrus cirrhosus, previously reported by [49], is here excluded from the Sardinian and Italian flora.

In the same way, Linum tenuifolium reported from Sardegna [50] and Urginea fugax from Basilicata [51] are not confirmed throughout this study. These species seem to have been recorded by mistake and are here excluded from the floras of these regions.

Thirty-four taxa are new for the regional floras of the study area: 6 were found in Lazio (Dichoropetalum carvifolium-chabraei, Geranium pusillum, Hieracium pallescens s.l., Lathyrus inconspicuus, Oeosporangium tinaei, and Veronica spicata subsp. spicata), 6 in Campania (Bupleurum rollii, Kickxia spuria subsp. spuria, Lupinus albus subsp. graecus, Plantago argentea subsp. argentea, Potamogeton pusillus, and Rumex maritimus), 17 in Basilicata (Alyssum diffusum subsp. garganicum, Bellevalia boissieri, Convolvulus siculus subsp. siculus, Daucus aureus, Epipactis schubertiorum, Eragrostis barrelieri subsp. barrelieri, Euphorbia stricta, Filago asterisciflora, Galanthus reginae-olgae subsp. vernalis, Isoetes duriei, Melampyrum barbatum subsp. carstiense, Nigella arvensis subsp. glaucescens, Ophrys crabronifera, Ophrys marmorata, Ophrys sipontensis, Quercus petraea subsp. austrotyrrhenica, Rosa subcollina, and Sempervivum tectorum) and 4 in Sardegna (Asplenium viride, Himantoglossum hircinum, Isopyrum thalictroides, and Oloptum miliaceum).

In addition, two hybrids within the genus Rosa are reported in Basilicata for the first time $(R . \times$ bishopii and $R$. montana $\times R$. villosa) and one (Populus $\times$ canescens) in Sardegna. We also confirm 10 taxa as present in the regions covered by this paper: Prangos ferulacea in Lazio; Pedicularis petiolaris, Potamogeton pusillus, Puccinellia festuciformis subsp. festuciformis, and Viola kitaibeliana in Campania; Trifolium spumosum in Basilicata; Melampyrum barbatum subsp. carstiense and Nigella arvensis subsp. glaucescens in Puglia, Muscari parviflorum and Ophrys speculum in Calabria region. Finally, for one species (Impatiens noli-tangere), reported for the first time in Basilicata in the recent checklist of the Italian vascular flora [16] on the basis of our unpublished data, full details about the record are provided.

\subsection{Alien taxa}

Three alien species are recognized new for Europe (excluding Azores and Madeira for M. excelsa) and for Italy: Epilobium nummularifolium, Metrosideros excelsa, found in Sardegna, and Salvinia minima, found in Calabria. In the same regions, we found Coprosma repens, Pittosporum crassifolium (Sardegna) recorded for the first time in Italy, and Commelina erecta, recorded for the first time in Italy (Calabria) outside Sicilia. In addition to those species, 31 new alien vascular species are reported at regional level (two of these are present in two regions): 2 in Lazio (Aubrieta columnae subsp. italica and Campanula poscharskyana); 2 in Campania (Conringia orientalis and Pinus nigra subsp. laricio); 12 in Basilicata (Anredera cordifolia, Chamaerops humilis, Euphorbia nutans, Fagopyrum esculentum, Ficus microcarpa, Gleditsia triacanthos, Kalanchoë $\times$ houghtonii, Lonicera japonica, Paspalum notatum, Phoenix canariensis, Pinus nigra subsp. laricio, and Tagetes erecta); 12 in Calabria (Asclepias physocarpa, Cenchrus longisetus, Commelina erecta, Nicandra physalodes, Nothoscordum gracile, Oxalis debilis, Oxalis latifolia, Phyllostachys aurea, Physalis peruviana, Plumbago auriculata, Solandra maxima, and Wisteria sinensis); 1 in Sicilia (Solandra maxima); 4 in Sardegna (Cordyline australis, Euphorbia nutans, Glandularia tenera, and 
Lantana montevidensis). Furthermore, the presence of Phyla nodiflora in Marche, Fagopyrum esculentum in Calabria (herein recorded as new also in Basilicata) and Tetragonia tetragonoides in Sardegna is confirmed.

\section{Discussion}

We reported 50 native taxa for the regions covered in this paper, including several endemic Italian taxa that are range extensions from their previous reported limits. The discovery in Sardegna of Cyclamen balearicum and Polygala rupestris, two species that had until now not been recorded for Italy, is particularly relevant because their presence provides additional support for the biogeographical link between Sardegna and the W-Mediterranean areas [52-54].

In the same way, the numerous neophytes reported for the first time in the regional floras once again confirm that alien species are continuously invading the environment. Although the majority of the recorded species have been evaluated with respect to their naturalization degrees as "casual," their monitoring over time is considered of primary importance in order to be able to effectively intervene if these species prove to be highly invasive. One especially noteworthy discovery is Salvinia minima, a species known to be invasive in most of the southern United States, where it is a significant threat to aquatic systems [55]. Salvinia minima is widely available for purchase for aquaria and water-gardens in Europe. Accordingly, we think that this species established in Italy from the aquatic plant trade, probably as an accidental introduction. The high number of floristic records of international and regional relevance provided, after a very short time from the publication of the latest Italian vascular flora checklist [16,17], even if not derived from a systematic sampling activity, testify of the importance to continuously implement our knowledge of plant diversity, especially for conservation purposes, studying and reviewing herbaria collections, coupled with frequent field surveys with special attention to achieve an early warning to monitor introduction and naturalization of alien taxa.

Author Contributions: Conceptualization, L.R., A.S., and E.F. (Emmanuele Farris); investigation, L.R., S.F., V.A.R., G.P., M.R.L., A.C., P.N., E.F. (Emmanuele Farris), P.J.d.L., E.D.V., L.F., E.F. (Emanuele Fanfarillo), E.L. (Edda Lattanzi), A.C.-O., M.M., M.C.F., E.B., E.L. (Erik Lallai), V.L.A.L., C.M.M., G.S. (Giovanni Spampinato), G.M. (Giacomo Mei)., G.M. (Giuseppe Misano), G.S. (Giovanni Salerno), A.E., A.S.; writing-original draft preparation, L.R., A.S., C.M.M., P.J.d.L., and E.F. (Emmanuele Farris); review, all the authors. All authors have read and agreed to the published version of the manuscript.

Funding: This research received no external funding.

Acknowledgments: We are grateful to G. Gottsclich for examining the Hieracium specimen; F. Ripullone and the project "Indagine conoscitiva e valorizzazione dell'area del bosco comunale Finocchio" for the supporting the botanical survey in the territory of Rotondella (Basilicata region).

Conflicts of Interest: The authors declare no conflict of interest.

\section{Appendix A}

Alyssum diffusum Ten. subsp. garganicum Španiel, Marhold, N. G. Passal. and Lihová

Brassicaceae Hemicryptophyte scapose Italian endemic

First record for Basilicata

Specimen: 8-4-2011, Difesa S. Biagio (Montescaglioso, Matera province), rocky outcrop within dry grassland, $155 \mathrm{~m}$ a.s.l., $40.5044^{\circ} \mathrm{N}-16.6876^{\circ} \mathrm{E}$, leg. et det S. Fascetti (HLUC).

Note: This endemic taxon was until now recorded only for Puglia region [56]. It is noteworthy to underline the presence in Basilicata of two infraspecific taxa of Alyssum diffusum: the subspecies calabricum Španiel, Marhold, N. G. Passal. and Lihová in the Campano-Lucano Apennine, along the border with Campania and Calabria regions [16] and the subsp. garganicum in the easter part, along the border in Puglia region.

Anredera cordifolia (Ten.) Steenis [三 Boussingaultia cordifolia Ten.]

Basellaceae Phanerophyte climbing Neophyte, S-America

First record for Basilicata (casual) 
Specimen: 15-6-2014, Lido di Policoro (Policoro, Matera province), roadside, $40.17361^{\circ} \mathrm{N}-16.70099^{\circ} \mathrm{E}$, $3 \mathrm{~m}$ a.s.l., leg. G. Salerno et M.R. Lapenna, det. G. Salerno (Herb. Salerno).

Note: Casual or naturalized alien species in most of the peninsular and insular regions except for Umbria [17]. It is considered an invasive taxon in Toscana [17].

Asclepias physocarpa (E. Mey.) Schltr. [三 Gomphocarpus physocarpus E. Mey.]

Apocynaceae Phanerophyte caespitose Neophyte, S-Africa

First record for Calabria (casual)

Specimen: 1-7-2019, Campo Calabro (Reggio Calabria province), roadside, $38.20633^{\circ} \mathrm{N}-15.64897^{\circ} \mathrm{E}$, leg. V.L.A. Laface, det. V.L.A. Laface et G. Spampinato (REGGIO).

Note: Five plants were recorded along the road, mixed with Hyparrhenia hirta (L.) Stapf. subsp. hirta and Rubus ulmifolius Schott. It was previously recorded as casual or naturalized alien species only in Toscana, Campania, and Sicilia regions [17].

Asplenium viride Huds.

Aspleniaceae Hemicryptophyte rosulate Circumboreal

First record for Sardegna

Specimen: 14-5-2013, Monte Albo (Siniscola, Nuoro province), $40.54141^{\circ} \mathrm{N}-9.62394^{\circ} \mathrm{E}$, sinkhole shaft in montane karstfield, $880 \mathrm{~m}$ a.s.l., leg. et det. P.J. de Lange (AK, SS).

Note. Recorded from all regions of Italy except for Puglia and doubtfully for Basilicata, but until now absent in the insular regions (Sardegna and Sicilia) [16]. However, Asplenium viride had been reported from Sardegna from a locality close to Fluminimaggiore (Iglesiente, South-western Sardegna) from where it has not since been seen [57]. Recently Ballero et al. [57] suggested its exclusion from the flora of Sardegna.

Image available at: https://inaturalist.nz/observations/4046536

Aubrieta columnae Guss. subsp. italica (Boiss.) Mattf. [三 A. italica Boiss.]

Brassicaceae Chamaephyte subshrubs Italian endemic

First record for Lazio (naturalized)

Specimen: 5-8-2019, Old town (Anticoli Corrado, Roma province), old walls, $500 \mathrm{~m}$ a.s.l., $42.00991^{\circ}$ $\mathrm{N}-12.99103^{\circ} \mathrm{E}$, leg. et det. L. Rosati (HLUC).

Note: A small population of this Italian endemic taxon, which grows in nature only in Puglia (Gargano peninsula) and doubtfully in Basilicata, was observed for over 10 years in anthropogenic habitat at Anticoli Corrado (Rosati, pers. observ.). These individuals have spread by seeds from a nearby cultivated plant in pots and urban gardens. Our specimens were identified using the key by [58].

Bellevalia boissieri Freyn [三 Bellevalia dubia (Guss.) Kunth subsp. boissieri (Freyn) Feinbrun]

Asparagaceae Geophyte bulbouse E-Mediterranean

First record for Basilicata

Specimen: 28-3-2018, Iazzo di Tucci (Rotondella, Matera province), olive groves, $40.17157^{\circ} \mathrm{N}-16.53832^{\circ}$

E, 298 m a.s.l., leg. G. Salerno et G. Misano, det. G. Salerno (Herb. Salerno).

Note: Until these discoveries this species was known from Italy only from the Calabria region [16].

Bupleurum rollii (Montel.) Moraldo [三 B. gracile d'Urv. var. rollii Montel.]

Apiaceae Therophyte scapose Italian endemic

First record for Campania

Specimen: 8-9-2013, Monte Vesole (Roccadaspide, Salerno province), chestnuts, $580 \mathrm{~m}$ a.s.1., $40.41156^{\circ}$ $\mathrm{N}-15.16761^{\circ} \mathrm{E}$, leg. et det. G. Salerno (Herb. Salerno).

Note. This Italian endemic had previously been recorded from Lazio to Sicilia, but not from Campania [16].

\section{Campanula poscharskyana Degen}

Campanulaceae Hemicryptophyte scap Neophyte, SE-European (Dinarides) 
First record for Lazio (casual)

Specimen: 5-8-2019, Old town (Roviano, Roma province), calcareous rock crevices, $495 \mathrm{~m}$ a.s.l., $42.02565^{\circ} \mathrm{N}-12.99403^{\circ} \mathrm{E}$, leg. et det. L. Rosati (HLUC).

Note: This alien species was reported as casual or naturalized only in Lombardia, Veneto, and Toscana [17].

Cenchrus longisetus M. C. Johnst. [= Pennisetum villosum R. Br. ex Fresen.]

Poaceae Hemicryptophyte caespitose Neophyte, Paleotropical

First record for Calabria (casual)

Specimen: 16-6-2019, San Roberto (Reggio Calabria province), sidewalks, $280 \mathrm{~m}$ a.s.1., 38.21074 ${ }^{\circ}$

$\mathrm{N}-15.736^{\circ}$ E, leg. V.L.A. Laface, det. V.L.A. Laface, C.M. Musarella et G. Spampinato (REGGIO).

Note: Collected from the margins of sidewalks where it was probably derived from a nearby flowerbed. This species has been recorded from Italian regions as casual or naturalized [17]; only in Sardegna is it considered invasive [17].

\section{Chamaerops humilis L.}

Arecaceae Nano-phanerophyte Neophyte, W-Mediterranean

First record for Basilicata (casual)

Specimen: 14-12-2017, S. Basilio, Marina di Pisticci (Pisticci, Matera province), clearings in mediterranean maquis, $3 \mathrm{~m}$ a.s.1., $40.2998^{\circ} \mathrm{N}-16.78265^{\circ} \mathrm{E}$, leg. et det. S. Fascetti (HLUC).

Note: Although this palm is indigenous to the neighboring regions of Campania and Calabria [16], it has not been recorded in the previous flora of Basilicata [51]. Therefore, as for the neighboring Puglia region [16], we consider it as introduced to this region. Plants probably spread from cultivation as the species was present in the nearby gardens, and only juvenile plants and seedlings were observed.

\section{Commelina erecta $\mathrm{L}$.}

Commelinaceae Terophyte crawling Archeophyte, C-America

First records for Calabria and peninsular Italy (casual)

Specimens: 23-6-2019, Lazzaro (Motta San Giovanni, Reggio Calabria province), crevices between road and sidewalks, $16 \mathrm{~m}$ a.s.1., $37.97394^{\circ} \mathrm{N}-15.66507^{\circ} \mathrm{E}$, leg. et det. C. M. Musarella (REGGIO); 25-6-2019, Catona (Reggio Calabria, Reggio Calabria province), sidewalks, $22 \mathrm{~m}$ a.s.l., $38.17987^{\circ} \mathrm{N}-15.64811^{\circ} \mathrm{E}$, leg. V.L.A. Laface, det. V.L.A. Laface, C.M. Musarella et G. Spampinato (REGGIO).

Note: Observed growing in crevices and on the edge of the roadside. Probably escaped from plants cultivated in pots placed on sidewalks. It was recently reported for the first time in Italy in Sicilia by [38].

Conringia orientalis (L.) Andrz. ex DC. [ $\equiv$ Brassica orientalis L.; $\equiv$ Gorinkia orientalis (L.) J. Presl and C. Presl]

Brassicaceae Therophyte scapose Neophyte, W-Asia

First record for Campania (casual)

Specimen: 15-5-2018, Campitello, Monti della Maddalena (Padula, Salerno province), forest edges, along a track, $1270 \mathrm{~m}$ a.s.l., $40.3452^{\circ} \mathrm{N}-15.68886^{\circ} \mathrm{E}$, leg. S. Fascetti, det S. Fascetti et L. Rosati (HLUC). Note: It is considered an archaeophyte associated with cereal crops, as stated for example in a previous record for Basilicata [59]. However, our finding of C. orientalis was in a silvo-pastoral habitat, quite far from cultivated areas.

\section{Convolvulus siculus L. subsp. siculus}

\section{Convolvulaceae Therophyte scapose S-Mediterranean}

First record for Basilicata

Specimen: 12-3-2012, Torre Caina (Maratea, Potenza province), clearings in mediterranean maquis, $39.94319^{\circ} \mathrm{N}-15.73534^{\circ} \mathrm{E}, 880 \mathrm{~m}$ a.s.l., leg. et det. G. Salerno (Herb. Salerno).

Note: It was previously recorded in Liguria, Toscana, Lazio, Campania, Puglia, Sicilia, and Sardegna regions [16]. 
Coprosma repens A. Rich.

Rubiaceae Nano-phanerophyte Neophyte, New Zealand

First record in Italy (casual)

Specimen: 10-03-2013, Torre Nuova, Porto Conte (Alghero, Sassari Province), occasional shrubs growing by old Spanish tower near beach, $2 \mathrm{~m}$ a.s.l., $40.593647^{\circ} \mathrm{N}-8.20430^{\circ} \mathrm{E}$, leg. et det. P.J. de Lange (AK).

Note: Growing among Myoporum laetum G. Forst., M. aff. insulare R. Br., M. laetum $\times$ M. aff. insulare. Plants with flower buds, seedlings present. In Europe, although it has been recorded only from Great Britain [60], this species was commonly seen by PdL along the coastline of southern France (1999, 2013), and northern Spain (Catalonia) (2013). It seems surprising it has not naturalized further as under the vernacular "mirror bush" it is recorded as an aggressive invasive species throughout much of the world [61].

Cordyline australis (G. Forst.) Endl. [三 Dracaena australis G. Forst.]

Asparagaceae Phanerophyte scapose Neophyte, New Zealand

First record for Sardegna (casual)

Specimen: 12-3-2012, Via Tarragona (Alghero, Sassari province), courtyard garden $30 \mathrm{~m}$ a.s.1., $40.55422^{\circ}$ $\mathrm{N}-8.32475^{\circ}$ E, leg. et det. P.J. de Lange (AK, SS).

Note: Seedling collected from rank grassland within inner courtyard garden. Growing close to planted adult fruiting trees. Although this species is a very commonly cultivated tree in Sardegna, so far, only sparingly naturalizing. This may be because mostly only one clone is grown, and the species is self-incompatible [62]. Outside Sardegna this species has been reported as a casual alien only in Marche, Abruzzo, and Campania [17].

Cyclamen balearicum Willk. [झ C. repandum Sm. subsp. balearicum (Willk.) O. Schwarz]

Primulaceae Geophyte bulbouse NW-Mediterranean

First record for Italy (Sardegna)

Specimen: 20-4-2008, Monte Doglia (Alghero, Sassari province), evergreen woodlands of Prasio majoris-Quercetum ilicis chamaeropetosum humilis, $40.60742^{\circ} \mathrm{N}-8.24683^{\circ} \mathrm{E}, 190 \mathrm{~m}$ a.s.l., leg. et det. E. Farris (SS).

Note: Cyclamen balearicum differs from C. repandum in having leaves usually adaxially speckled with white and flowers that are either fully white or with a white-veined pale pink corolla [42]. Recent research $[63,64]$ highlighted the presence of a hybrid zone between Cyclamen repandum and C. balearicum in NW Sardegna, where hybrid plants displaying bi-colored flowers prevail, and pure C. balearicum plants were scarce. However, based on the original observations, at Mt. Doglia plants with small white flowers and non-exerted stigma are dominant, though only occasional individuals have the diagnostic leaf ornamentation of $C$. balearicum s.s. The nearest known localities of this species according to Flora Gallica and Flora Iberica are in Corsica (France), Provence (S-France), and Balearic Islands (Spain).

\section{Daucus aureus Desf.}

Apiaceae Therophyte scapose S-Mediterranean

First record for Basilicata

Specimen: 1-5-2019, Serra delle Grotte (Rotondella, Matera province), fallows on clay soils, $120 \mathrm{~m}$ a.s.l., 40.19691 N-16.49405 E, leg. G. Salerno et G. Misano, det. G. Salerno (Herb. Salerno).

Note: At present known only from Calabria and Sicilia [16]. There are historical doubtful records of this species from Liguria and Campania, respectively [16].

Dichoropetalum carvifolium-chabraei (Crantz) Soldano, Galasso and Banfi [ $\equiv$ Selinum carvifolium-chabraei Crantz; - Holandrea carvifolia Reduron, Charpin and Pimenov; = Peucedanum carvifolium-chabraei (Crantz) Soldano]

Apiaceae Hemicryptophyte scapose European-Caucasian 
First record for Lazio

Specimen: 16-7-2015, Monte Tilia, Fondo del Laghetto (Leonessa, Rieti province), secondary grassland with Brachypodium genuense, marly-calcareous slopes, $1400 \mathrm{~m}$ a.s.l., $42.55842^{\circ} \mathrm{N}-12.95441^{\circ} \mathrm{E}$, leg. et det. E. Del Vico (Herb. Del Vico).

Note: In Italy it is reported in many northern and central regions and in Sicilia [16].

Epilobium nummularifolium R. Cunn. ex A. Cunn.

Onagraceae Hemicryptophyte crawling Neophyte, New Zealand

First record for Italy (casual)

Specimen: 24-04 2013, via Castelsardo (Alghero, Sassari province), damp ground on side of road adjacent pasture used for hay making, $6 \mathrm{~m}$ a.s.l., $40.57221^{\circ} \mathrm{N}-8.32010^{\circ} \mathrm{E}$, leg. et det. P.J. de Lange (AK, SS).

Note: Image of Epilobium nummularifolium at this locality available at: https://inaturalist.nz/observations/ 4437892.

Epilobium nummularifolium is apparently not known wild elsewhere in greater Europe [65]. However, this species has a superficial similarity to E. brunnescens (Cockayne) Raven et Engelhorn subsp. brunnescens, which is abundantly naturalized in the British Isles, and reported from the Guernesy Islands, so it is possible that it has been confused with that species, and so overlooked [65]. E. nummularifolium, a New Zealand endemic, is well-known for its aggressive, weedy nature. Raven and Raven [65] argue that this species was once a narrow range endemic of northern New Zealand, which has spread throughout that archipelago as a garden plant pot contaminant. We suspect that this is how it has reached Sardegna, i.e., as a possible soil/garden plant contaminant, introduced alongside anyone of the many New Zealand indigenous/endemic plants seen there in cultivation. This species should be looked for elsewhere in Europe. Epilobium nummularifolium is distinguished from both E. brunnescens and E. komarovianum H. Lev, which is also naturalized in Europe [65] by the yellow-green, serrulate leaves, purple-blue stems, and grey-strigulose capsules [65-68] (Table A1, Figure A1). These species are keyed out as follows:

1. Adaxial leaf surface deeply rugose-impressed

1. Adaxial leaf surface smooth, not rugose-impressed

E. komarovianum

2. Leaves yellow-green, with red margins, serrulate bearing 2-11 pairs of teeth either side of midrib; stems purple-blue, capsules grey-strigulose

E. nummularifolium

2. Leaves dark green, tinged red or brown, entire or with 1-4 pairs of indistinct teeth either side of midrib, capsules glabrate, rarely very sparsely hairy

E. brunnescens

Table A1. Distinguishing characters between three New Zealand creeping Epilobium species naturalized in Europe/British Isles.

\begin{tabular}{|c|c|c|c|}
\hline & $\begin{array}{l}\text { E. brunnescens subsp. } \\
\text { brunnescens }\end{array}$ & E. komarovianum & E. nummularifolium \\
\hline Growth habit & $\begin{array}{l}\text { Densely matted, creeping herb } \\
\text { forming patches up to } 1 \mathrm{~m} \\
\text { diameter }\end{array}$ & $\begin{array}{l}\text { Matted, creeping herb forming patches of } \\
\text { tightly appressed stems and leaves up to } 1 \\
\text { m diameter (usually less) }\end{array}$ & $\begin{array}{l}\text { Loosely matted, creeping herb } \\
\text { patches up to } 1 \mathrm{~m} \text { diameter }\end{array}$ \\
\hline Stems & Light brown & Yellow-green & Purple-blue \\
\hline Leaves & $\begin{array}{l}\text { Dull green often with a red or } \\
\text { brown-tinge, bearing } 0-1(-2) \\
\text { obscure lateral veins either } \\
\text { side of midrib; lamina } 1.5-13.0 \\
\times 1.5-12.0 \text { mm ovate to } \\
\text { broadly ovate, apex rounded } \\
\text { to obtuse, base obtuse to } \\
\text { truncate, entire, rarely with } \\
\text { 1-2(-4) weakly developed } \\
\text { teeth on each margin }\end{array}$ & $\begin{array}{l}\text { Dull reddish-green to coppery, adaxially } \\
\text { rugose-impressed, bearing 1-4 lateral veins } \\
\text { on each side of the midrib; lamina } 2.0-12.0 \\
\times 1.5-9.0 \mathrm{~mm} \text {, usually orbicular, but } \\
\text { occasionally oblong or ovate (sometimes } \\
\text { with all forms on the same plant), apices } \\
\text { subacute to obtuse, base attenuate to } \\
\text { obtuse, entire or occasionally with } 1-3 \\
\text { remote, weak teeth on each side of leaf }\end{array}$ & $\begin{array}{l}\text { Yellowish-green, usually with } \\
\text { red margins and } 1-3(-4) \\
\text { inconspicuous lateral veins on } \\
\text { either side of the midrib; lamina } \\
3.0-13.0 \times 3-11.0 \text { mm, broadly } \\
\text { ovate to oblate, obtuse or } \\
\text { rounded at apex, rounded to } \\
\text { truncate at base, margins } \\
\text { remotely and shallowly serrulate } \\
\text { with 2-11 teeth on either side }\end{array}$ \\
\hline
\end{tabular}


Table A1. Cont.

\begin{tabular}{cccc}
\hline & $\begin{array}{c}\text { E. brunnescens subsp. } \\
\text { brunnescens }\end{array}$ & E. komarovianum & E. nummularifolium \\
\hline Flowers & $\begin{array}{c}\text { Flowers nodding, falling } \\
\text { before full pedicel elongation } \\
\text { is achieved }\end{array}$ & $\begin{array}{c}\text { Flowers falling before full pedicel } \\
\text { elongation is achieved }\end{array}$ & $\begin{array}{c}\text { flowers falling when pedicel } \\
\text { elongation is complete }\end{array}$ \\
\hline Capsules & $\begin{array}{c}\text { Capsule glabrate or sparsely } \\
\text { hairy, indumentum of } \\
\text { appressed glandular or erect } \\
\text { glandular or glandular hairs } \\
\text { running along lines of } \\
\text { dehiscence, 12-60 mm long, } \\
\text { borne on a glabrous pedicel } \\
(16-) 35-80(-120) \text { mm long }\end{array}$ & $\begin{array}{c}\text { Capsule subglabrous or sparsely furnished } \\
\text { with hairs, 4-30 mm long, borne on a } \\
\text { pedicel 3-93(-135) mm long }\end{array}$ & $\begin{array}{c}\text { Capsule densely grey-strigulose, } \\
(10-) \text { - } 15-40 \mathrm{~mm} \text { long, borne on a } \\
\text { strigulose pedicel 23-130 mm } \\
\text { long }\end{array}$ \\
\hline
\end{tabular}
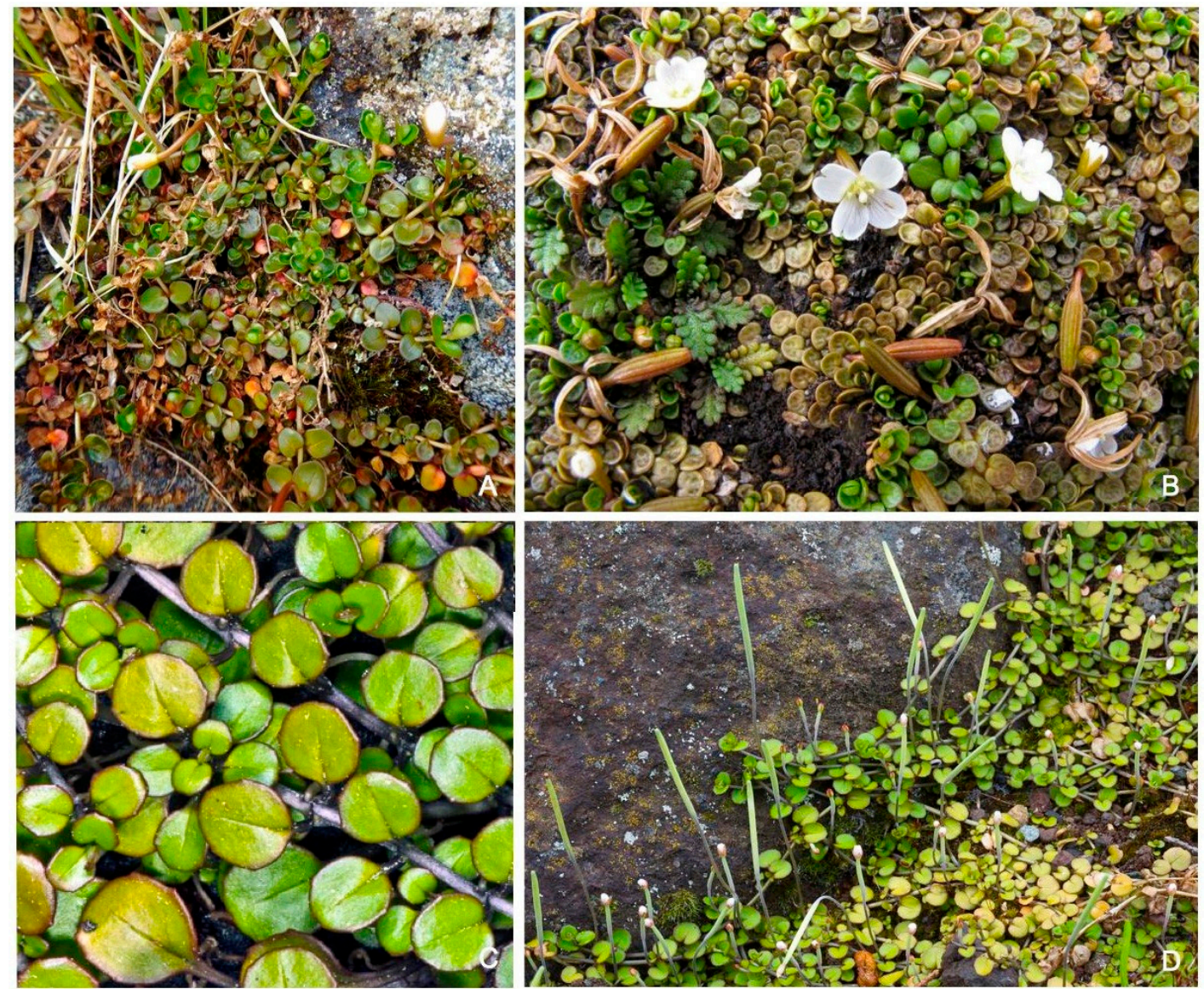

Figure A1. Comparison images of three New Zealand creeping Epilobium species naturalized in Europe/British Isles: (A) Epilobium brunnescens subsp. brunnescens fruiting plant showing growth habit, Mt Te Aroha, North Island, New Zealand, image: P.J. de Lange; (B) E. komarovianum, flowering plant with immature capsules, showing distinctive rugose-impressed leaves, Long Point, Otago, South Island, New Zealand, image: J.W. Barkla; (C) E. nummularifolium, vegetative material showing growth habit, note stem and leaf color and toothed leaf margins; Alghero, Sardegna, image: P. J. de Lange; ( D) E. nummularifolium flowering and fruiting plant (note greyish color of capsules); Centre Road, Otago Peninsula, South Island, New Zealand image: D. Lyttle.

Epipactis schubertiorum Bartolo, Pulv. and Robatsch [三 Epipactis helleborine (L.) Crantz subsp. schubertiorum (Bartolo, Pulv. and Robatsch) Kreutz]

Orchidaceae Geophyte rhizomatous Italian endemic

First record for Basilicata

Observatum: 25-7-2017, Abetina di Laurenzana (Viggiano, Potenza province), Abies alba and Quercus cerris forest, $1130 \mathrm{~m}$ a.s.1., $40.40708^{\circ} \mathrm{N}-15.95478^{\circ} \mathrm{E}$, leg. et det. V.A. Romano (HLUC). 
Note: This Italian endemic species had previously been recorded only from Puglia and Calabria [16].

Eragrostis barrelieri Daveau subsp. barrelieri

Poaceae Therophyte scapose S-Mediterranean

First record for Basilicata

Specimen: 16-6-2014, Concio, Sinni river (Policoro, Matera province), roadside, $40.17126^{\circ} \mathrm{N}-16.64227^{\circ}$ E, $10 \mathrm{~m}$ a.s.l., leg. et det. G. Salerno (Herb. Salerno).

Note: In Italy it is recorded for some northern and central regions, Sicilia and Sardegna [16].

Euphorbia nutans Lag. [ $\equiv$ Chamaesyce nutans (Lag.) Small]

Euphorbiaceae Therophyte scapose Neophyte, N-America

First record for Basilicata (casual) and Sardegna (casual)

Specimens: 3-8-2017, Porto (Maratea, Potenza province), roadside, $15 \mathrm{~m}$ a.s.l., $39.98978^{\circ} \mathrm{N}-15.70888^{\circ} \mathrm{E}$, leg. A. Stinca et M. Eviano, det. A. Stinca (PORUN-Herb. Stinca); 20-8-2017, along SS18 road, close by loc. La Torre (Maratea, Potenza province), roadside, $60 \mathrm{~m}$ a.s.l., $40.03127^{\circ} \mathrm{N}-15.67405^{\circ} \mathrm{E}$, leg. A. Stinca et M. Ravo, det. A. Stinca (PORUN-Herb. Stinca); 29-9-2019, Tuerredda (Teulada, Cagliari province), pots and paths along the dune, $2 \mathrm{~m}$ a.s.l., $38.89686^{\circ} \mathrm{N}-8.81394^{\circ} \mathrm{E}$, leg. et det. L. Rosati et $\mathrm{M}$. Marignani (HLUC).

Note: Euphorbia nutans was recorded as casual or naturalized alien in most of the Italian regions [17]. It is considered invasive in Lombardia and Veneto [17].

Euphorbia stricta L. [= Euphorbia serrulata Thuill.]

Euphorbiaceae Therophyte scapose European-Caucasian

First record for Basilicata and confirmation for peninsular Italy

Specimen: 12-6-2018, Vascarano, Pergola (Marsico Nuovo, Potenza province), traditional arable land, $915 \mathrm{~m}$ a.s.1., $40.42385^{\circ} \mathrm{N}-15.68713^{\circ} \mathrm{E}$, leg. et det. L. Rosati (HLUC).

Note: Previously, and reliably reported only from the northern Italian regions [16]; this record provides the first verified evidence of its presence in peninsular Italy. Previously it was considered as doubtfully present in Lazio [16], while it has not been recently recorded from Abruzzo and Calabria [16], and was apparently recorded by mistake from Sicilia [16].

\section{Fagopyrum esculentum Moench}

Polygonaceae Therophyte scapose Neophyte, Asia

First record for Basilicata (casual) and confirmation for Calabria (casual)

Specimens: 7-9-2011, Diga Masseria Nicodemo, Lago di Cogliandrino (Lauria, Potenza province), fallows, mesic grasslands, $670 \mathrm{~m}$ a.s.1., $40.08151^{\circ} \mathrm{N}-15.93680^{\circ}$ E, leg. et det. S. Fascetti (HLUC); 30-8-2017, Contrada Schiena La Torre (Verbicaro, Cosenza province), vegetable garden, $575 \mathrm{~m}$ a.s.l., $39.76166^{\circ}$ $\mathrm{N}-15.89780^{\circ}$ E, leg. et det. S. Fascetti (HLUC).

Note: This species is known with certainty only from the northern Italian regions [17]; otherwise considered doubtfully present in Lazio, and not recently confirmed from Abruzzo and Calabria (after 1950) [17]. In Basilicata it was observed escaping from small cultivated fields of buckwheat. In the Calabria region it was observed for some years as a weed of vegetable gardens and along arable land edges.

Ficus microcarpa L. f. [- Ficus retusa auct. p.p., non L.]

Moraceae Phanerophyte scapose Neophyte, E-Asia

First record for Basilicata (casual)

Specimen: 3-8-2017, Porto (Maratea, Potenza province), walls and crevices in the road pavements, $5 \mathrm{~m}$ a.s.l., $39.98949^{\circ} \mathrm{N}-15.70868^{\circ} \mathrm{E}$, leg. A. Stinca et M. Eviano, det. A. Stinca (PORUN-Herb. Stinca).

Note: Treated as a casual alien in Sardegna, Campania, and Puglia; naturalized in Sicilia [17]. Recently recorded in southern Italy for Calabria [14].

Filago asterisciflora (Lam.) Sweet [ $\equiv$ Gnaphalium asterisciflorum Lam.; E Evax asterisciflora (Lam.) Pers.] Asteraceae Therophyte crawling Steno-Mediterranean 
First record for Basilicata

Specimen: 2-5-2019, Bosco Finocchio (Rotondella, Matera province), roadside, $40.15282^{\circ} \mathrm{N}-16.47588^{\circ} \mathrm{E}$, $600 \mathrm{~m}$ a.s.l., leg. G. Salerno et G. Misano det. G. Salerno (Herb. Salerno).

Note: Previously Filago asterisciflora has been recorded from Toscana, Lazio, Campania, Puglia, Calabria, Sicilia, and Sardegna [16].

Galanthus reginae-olgae Orph. subsp. vernalis Kamari

Amaryllidaceae Geophyte bulbouse European-Caucasian

First record for Basilicata

Specimen: 20-2-2014, Sellata (Pignola, Potenza province), beech forest, $1270 \mathrm{~m}$ a.s.1., $40.53127^{\circ}$ $\mathrm{N}-15.78871^{\circ}$ E, leg. et det. S. Fascetti (HLUC).

Note: Several plants observed in a large population extending for approximately $200 \mathrm{~m}^{2}$. Previously reported from the Calabria and Sicilia regions [16].

\section{Geranium pusillum L.}

Geraniaceae Therophyte scapose Eurasian

First record for Lazio

Specimen: 4-6-2015, Colle Pietrolone (Poggio Bustone, Rieti province), secondary grassland with Bromus hordeaceus, Poa trivialis and Poa sylvicola, gently marly slopes, $1070 \mathrm{~m}$ a.s.1., $42.50015^{\circ} \mathrm{N}-12.90332^{\circ}$ E, leg. E. Del Vico et L. Facioni, det. E. Del Vico (Herb. Del Vico).

Note: It was previously recorded in all Italian regions except for Lazio and Sicilia [16].

Glandularia tenera (Spreng.) Cabrera [三 Verbena tenera Spreng.; 三Shuttleworthia tenera (Spreng.) Walp.] Verbenaceae Chamaephyte subshrubs Neophyte, S-America

First record for Sardegna (casual)

Specimen: 27-4-2019, Colle S. Michele (Cagliari, Cagliari province), grassland, $95 \mathrm{~m}$ a.s.1., 39.24345 $\mathrm{N}-9.11095^{\circ}$ E, leg. et det. L. Rosati et M. Marignani (HLUC).

Note: It was previously recorded only for Lazio as casual [17]. Plant samples were identified using the diagnostic characters and keys of [69-71].

\section{Gleditsia triacanthos $\mathrm{L}$.}

Fabaceae Phanerophyte scapose, Neophyte, N-America

First record for Basilicata (casual)

Specimen: 25-5-2017, M. Vulture, Foggianello (Rionero in Vulture, Potenza province), forest edges and road side, $570 \mathrm{~m}$ a.s.l., $40.96473^{\circ} \mathrm{N}-15.59563^{\circ} \mathrm{E}$, leg. et det. E. Fanfarillo et L. Rosati (HLUC)

Note: Previously reported from all Italian regions except for Molise and Basilicata [17].

Hieracium pallescens Waldst. and Kit. s.l.

Asteraceae Hemicryptophyte scapose SE-European

First record for Lazio

Specimen: 29-7-2015, Rifugio Sebastiani, Monte Terminillo (Rieti province), pastured grassland dominated by Bromopsis erecta with Helictochloa praetutiana, Brachypodium genuense, Carex kitaibeliana, and Festuca violacea subsp. italica, limestone, $1870 \mathrm{~m}$ a.s.l., $13.01343^{\circ} \mathrm{N}-42.46902^{\circ} \mathrm{E}$, leg. E. Del Vico et L. Facioni, det. G. Gottsclich (Herb. Del Vico).

Note: This species is present in all the northern regions of Italy except for Liguria [16]. In peninsular Italy it was recorded only from Abruzzo, Campania, Basilicata, and Calabria [16]. About twenty subspecies of $H$. pallescens are present in Italy; however, our specimen does not allow to ascertained the subspecific level. Further on filed investigations should be performed to fix this gap.

Himantoglossum hircinum (L.) Spreng. [三 Satyrium hircinum L.]

Orchidaceae Geophyte bulbouse Mediterranean-Atlantic

First record for Sardegna

Specimen: 22-5-2013, Illorai forest (Illorai, Sassari province), within a small clearing in otherwise dense Quercus ilex and Q. pubescens forest, $40.40494^{\circ} \mathrm{N}-8.92588^{\circ}$ E, photo et det. P. J. de Lange. 
Note: This species is present in Italy in the north-western (Piemonte, Liguria, Toscana and Emilia-Romagna) and in the southern regions with a clear gap in central Italy [16]. Although it is a very showy orchid it was never seen before in Sardegna, probably because of its rarity.

Images available at: https://inaturalist.nz/observations/4060025

Impatiens noli-tangere $\mathrm{L}$.

Distribution clarification for Basilicata

Balsaminaceae Therophyte scapose Eurasian

Specimen: 31-7-2015, Fossa Cupa (Sasso di Castalda, Potenza province), Fagus sylvatica forest, $40.50972^{\circ}$ $\mathrm{N}-15.73002^{\circ}$ E, leg. V.A. Romano, det. L. Rosati (HLUC).

Note: This species was reported first from Basilicata by Bartolucci et al. [16] based on our unpublished record above. Here we provide full details of the discovery.

Isoëtes durieui Bory

Isoëtaceae Geophyte bulbouse W-Steno-Mediterranean

First record for Basilicata

Specimen: 2-5-2019, Bosco Finocchio (Rotondella, Matera province), ponds within Quercus cerris forest, 600 m a.s.1., $40.15282^{\circ} \mathrm{N}-16.47588^{\circ}$ E, leg. G. Salerno et G. Misano, det. G. Salerno (Herb. Salerno).

Note: It was previously recorded for all western Italian regions though considered doubtfully in Molise [16].

\section{Isopyrum thalictroides $\mathrm{L}$.}

Ranunculaceae Geophyte rhizomatous Eurasian

First record for Sardegna

Specimen: 15-6-2014, Fontana Is Bidileddos (Desulo, Nuoro province), riparian forest of Glechomo sardoae-Alnetum glutinosae, $1660 \mathrm{~m}$ a.s.1., $40.01029^{\circ} \mathrm{N}-9.309394^{\circ} \mathrm{E}$, leg. et det. E. Farris (SS).

Note: Locally common on the Fonni mountain side, exclusively in Alnus glutinosa forests above $1500 \mathrm{~m}$ a.s.l. (see https://inaturalist.nz/observations/4112222). This taxon is present throughout Italy, in most of the central-northern regions of Italy and though absent south of Toscana [16]. Our finding is the first for Mediterranean islands. This is noteworthy as it is believed to be absent from Corsica [72].

Kalanchoë $\times$ houghtonii D. B. Ward [三 Bryophyllum $\times$ houghtonii (D. B. Ward) P. I. Forst.; Kalanchoë daigremontiana Raym. -Hamet and H. Perrier $\times$ Kalanchoë delagoensis Eckl. and Zeyh.]

Crassulaceae Ch succulent Neophyte, horticultural origin

First record for Basilicata (naturalized)

Specimen: 3-8-2017, Porto (Maratea, Potenza province), calcareous sea cliffs, $6 \mathrm{~m}$ a.s.1., 39.98835 $\mathrm{N}-15.70995^{\circ}$ E, leg. A. Stinca et M. Eviano. det. A. Stinca (PORUN-Herb. Stinca).

Note: At Maratea Kalanchoë $\times$ houghtonii seems to form populations capable of self-sustaining reproduction. Indeed, because of the viviparous nature, whereby the leaf lamina produces myriad plantlets this species has the potential to be highly invasive. It is recorded as naturalized from Liguria, Toscana, Lazio, and Calabria; it is present as casual in Campania, Puglia, Sardegna, and Sicilia [17].

Kickxia spuria (L.) Dumort. subsp. spuria [三 Antirrhinum spurium L. subsp. spurium]

Plantaginaceae Therophyte scapose Eurasian

First record for Campania

Specimen: 29-7-2014, near Vallone Serra Melito (Capaccio Paestum, Salerno province), arable land, $40.41596^{\circ} \mathrm{N}-15.08801^{\circ} \mathrm{E}$, leg. et det. A. Stinca (PORUN-Herb. Stinca).

Note: This is the first record for the Southern Italian peninsula [16].

Lantana montevidensis (Spreng.) Briq. [三 Lippia montevidensis Spreng.]

Verbenaceae Nano-phanerophyte Neophyte, S-America

First record for Sardegna (casual)

Specimen: 30-8-2018, Su Giudeu (Domus de Maria, Cagliari province), crevices in the walls, $5 \mathrm{~m}$ a.s.l., $38.88749^{\circ} \mathrm{N}-8.85886^{\circ} \mathrm{E}$, leg. et det. L. Rosati et M. Marignani (HLUC). 
Note: Previously reported as a casual alien only from Liguria and Calabria regions [17]. In Sardegna this species is widely grown in urban green areas, pots, and Mediterranean gardens (pers. observ.) so further naturalizations are likely.

\section{Lathyrus cirrhosus Ser.}

Fabaceae Hemicryptophyte NW-Steno-Mediterranean

Exclusion for Italy (Sardegna)

Note: This taxon was reported only once at Monte Arviganu and Monte S. Giuliano, near Alghero, Sardegna by Schmid [49]. Pignatti [19,47] and Arrigoni [73] stated that the presence of L. cirrhosus in Sardegna is doubtful because of the probable confusion with L. heterophyllus L. Nevertheless, it was considered present in Sardegna in the Italian Flora checklists of vascular plants [16,74]. We have unsuccessfully searched for this species in the two sites during the last decade, and in the absence of verified herbarium evidence of its historic presence we recommend that L. cirrhosus be excluded from the flora of Sardegna and Italy.

\section{Lathyrus inconspicuus L.}

Fabaceae Therophyte scapose Euri-Mediterranean

First records for Lazio

Specimens: 11-6-2015, Monte Porillo (Micigliano, Rieti province), secondary grassland with Bromopsis erecta and Brachypodium rupestre, gently marly slopes, $1000 \mathrm{~m}$ a.s.1., $42.45552^{\circ} \mathrm{N}-13.06439^{\circ} \mathrm{E}$, leg. E. Del Vico et L. Facioni, det. E. Del Vico (Herb. Del Vico); 28-6-2016, Micigliano (Rieti province), secondary grassland with Bromopsis erecta and Brachypodium rupestre, gently marly slopes, $1130 \mathrm{~m}$ a.s.1., $42.46011^{\circ}$ N-13.06226 ${ }^{\circ}$ E, leg. et det. E. Del Vico (Herb. Del Vico); 8-6-2016, Monte Porillo (Micigliano, Rieti province), secondary grassland with Bromopsis erecta and Brachypodium rupestre, gently marly slopes, 1130 m a.s.1., $42.46301^{\circ} \mathrm{N}-13.05907^{\circ}$ E, leg. E. Del Vico et S. Bonacquisti, det. E. Del Vico (Herb. Del Vico); 20-7-2016, Monte Porillo (Micigliano, Rieti province), secondary grassland with Cynosurus cristatus, 1110 m a.s.l., $42.46596^{\circ}$ N-13.06396 E, leg. et det. E. Del Vico (Herb. Del Vico); 20-7-2016, Erta (Micigliano, Rieti province), secondary grassland with Brachypodium rupestre, marly substratum, 1110 $\mathrm{m}$ a.s.l., $42.46428^{\circ} \mathrm{N}-42.46428^{\circ}$ E, leg. et det. E. Del Vico (Herb. Del Vico).

Note: In peninsular Italy L. incospicuus was previously recorded from Toscana, Marche, Abruzzo, and Puglia; indeed, in Umbria and Campania its presence is doubtful [16]. It is absent in the southern and insular regions [16].

\section{Linum tenuifolium $\mathbf{L}$.}

Linaceae Chamaephyte subshrubs Steno-Mediterranean-Euxinian

Exclusion for Sardegna

Note: The presence of this taxon in Sardegna was reported by Mossa et al. [50] and so accepted in the Italian checklist of vascular flora [16,74]. Nevertheless, the species is excluded by [75] who considers its presence a mistake, because of the confusion with L. bienne. Our surveys in the site from where Linum tenuifolium was reported by Mossa et al. [50] found only L. bienne. Therefore, L. tenuifolium has to be excluded from Sardegna. It was also reported by mistake in Sicilia region [16].

\section{Lonicera japonica Thunb.}

Caprifoliaceae Phanerophyte climbing Neophyte, E-Asia

First record for Basilicata (casual)

Specimen: 14-6-2019, Macchia Romana, Campus of University of Basilicata (Potenza), crevices in road pavements close to the walls, $40.68829^{\circ} \mathrm{N}-15.80848^{\circ} \mathrm{E}, 735 \mathrm{~m}$ a.s.l, leg. et det. L. Rosati (HLUC).

Note: Lonicera japonica has been recorded from all Italian regions except for Molise and Basilicata [17]. It is considered invasive in several regions of Northern Italy [17].

Lupinus albus L. subsp. graecus (Boiss. and Spruner) Franco and P. Silva [ $\equiv$ L. graecus Boiss. and Spruner]

Fabaceae Therophyte scapose E-Steno-Mediterranean 
First record for Campania

Specimen: 22-4-2011, M. Vesole (Roccadaspide, Salerno province), chestnuts, $40.41538^{\circ} \mathrm{N}-15.17548^{\circ} \mathrm{E}$, $500 \mathrm{~m}$ a.s.l., leg. et det. G. Salerno (Herb. Salerno).

Note: Previously reported from the Italian Peninsula for all of the regions, except Abruzzo, Molise, and Campania [16].

\section{Melampyrum barbatum Waldst. and Kit. subsp. carstiense Ronniger}

Orobanchaceae Therophyte scapose SE-European

First record for Basilicata and confirmation for Puglia

Specimens: 9-6-1981, Trivigno (Potenza), oak forests, $500 \mathrm{~m}$ a.s.1., $40.58074^{\circ} \mathrm{N}-15.98965^{\circ}$ E, legit et det. F. Cremonini (HLUC); 6-6-2018, V.ne Mariano (Laurenzana, Potenza province), edge of Quercus pubescens woods, siliceous substratum, $40.48337^{\circ} \mathrm{N}-15.96811^{\circ} \mathrm{E}$, leg. L. Rosati et G. Potenza, det. L. Rosati (HLUC); 20-7-2014, Foresta Umbra (Vico del Gargano, Foggia province), roadside of forest road and edge of forest clearing, $560 \mathrm{~m}$ a.s.l, $41.854115^{\circ} \mathrm{N}-16.001818^{\circ} \mathrm{E}$, leg. et det. G. Mei (ANC, Herb. Mei). Note: In Southern Italy previously known only from doubtful historic records [16].

Metrosideros excelsa Sol. ex Gaertn. [= M. tomentosa A. Rich.; = Nania tomentosa (A. Rich.) Kuntze] Myrtaceae Phanerophyte caespitose Neophyte, New Zealand

First record for Europe (Azores and Madeira excluded) (casual)

Specimen: 31-5-2013, Costa Rei, Monte Nai (Muravera, Cagliari province), urban areas, $20 \mathrm{~m}$ a.s.l., $39.2565^{\circ} \mathrm{N}-9.575611^{\circ} \mathrm{E}$, leg. et det. P.J. de Lange (AK, SS).

Note: A few seedlings, and saplings growing in the vicinity of the planted adult trees; this species is common in many coastal towns and resorts around Sardegna (see for example https://inaturalist.nz/ observations/1715168). Metrosideros excelsa, commonly known as "New Zealand Christmas tree," is a coastal evergreen tree that produces a brilliant display of red flowers. It has been recently added to the list of host plants referred to in Article 1(b) of Commission Implementing Decision (EU) 20152417 of 17 December 2015, which have been found to be susceptible to Xylella fastidiosa in the European Union territory.

Until this record Metrosideros excelsa had been recorded in Europe as a naturalized plant only from the Azores and Madeira (Portugal) by [76]. Thus, our finding represents the first record for Europe (Azores and Madeira excluded).

Muscari parviflorum Desf.

Asparagaceae Geophyte bulbouse Central-E-Mediterranean

Confirmation for Calabria

Specimen: 10-10-2011, Orsomarso (Cosenza), fallows, $488 \mathrm{~m}$ a.s.1., $39.78545^{\circ} \mathrm{N}-15.90759^{\circ} \mathrm{E}$, leg. et det S. Fascetti (HLUC).

Note: Previous records of this species from Calabria had been considered doubtful [16].

Nicandra physalodes (L.) Gaertn. [” Atropa physalodes L.]

Solanaceae Therophyte scapose Neophyte, S-American

First record for Calabria (casual)

Specimen: 3-6-2019, S. Litterata (Belvedere Marittimo, Cosenza province), fallows, $35 \mathrm{~m}$ a.s.l., $39.65594^{\circ}$ $\mathrm{N}-15.83856^{\circ}$ E, leg. et det. A. Capano (HLUC).

Note: This species was recorded in Italy from several regions; it is present in almost all of the central and northern regions as a casual alien; in Piemonte, Trentino-Alto Adige, and Friuli-Venezia Giulia it is considered naturalized [17]. It is absent in most of the southern regions, except for Sicilia [17].

Nigella arvensis L. subsp. glaucescens (Guss.) Greuter and Burdet [झ N. arvensis L. var. glaucescens Guss.]

Ranunculaceae Therophyte scapose Euri-Mediterranean

First record for Basilicata and confirmation for Puglia 
Specimens: 15-4-2019, Padula (Ferrandina, Matera province), fallows, $40.5237^{\circ} \mathrm{N}-16.39444^{\circ} \mathrm{E}$, leg. G. Marsilio, det. L. Rosati (HLUC); 15-4-2019, Accetta Grande (Statte, Taranto province), herbaceous fallows, $500 \mathrm{~m}$ a.s.l., $40.55389^{\circ} \mathrm{N}-17.17667^{\circ} \mathrm{E}$, leg. G. Santoro, det. G. Santoro et L. Rosati (HLUC).

Note: Previously it was only recorded from Calabria, Sicilia, and Sardegna; no recent records are found from Puglia [16]. The presence of this taxon in Basilicata (Matera and Potenza Province) was also reported in the Forum Acta Plantarum ("Nigella arvensis subsp. glaucescens (Guss.) Greuter and Burdet-Scheda IPFI, Acta Plantarum." Available on line (access date: 02-10-2019): http:\$\delimiter"026E30F\$ \$delimiter"026E30F\$www.actaplantarum.org\$ \delimiter" 026E30F\$flora\$ \delimiter"026E30F\$flora_info.php?id=5297).

Nothoscordum gracile (Aiton) Stearn [三 Allium gracile Aiton]

Amaryllidaceae Geophyte bulbouse Neophyte, S-America

First record for Calabria (casual)

Specimen: 3-5-2019, Lazzaro (Motta San Giovanni, Reggio Calabria province), crevices in the sidewalks, $17 \mathrm{~m}$ a.s.l., $37.97408^{\circ} \mathrm{N}-15.66485^{\circ} \mathrm{E}$, leg. et det. C.M. Musarella (REGGIO).

Note: Probably escaped from cultivated plants growing in pots placed on the sidewalks from where it had spread into crevices and the edge of the roadside. It was recorded as naturalized in Toscana, Campania, and Puglia [17] and as casual alien in Piemonte, Liguria, and Sardegna [17].

Oeosporangium tinaei (Tod.) Fraser-Jenk. [三 Cheilanthes tinaei Tod.; = C. corsica Reichst. and Vida]

Pteridaceae Hemicryptophyte rosulate Steno-Mediterranean-Macaronesian

First record for Lazio

Specimen: 23-5-2012, Cerveteri (Roma province), trachytes steep slope, $60 \mathrm{~m}$ a.s.l., $42.00000^{\circ} \mathrm{N}-12.10000^{\circ}$ E, leg. et det. E. Del Vico et L. Facioni (HRO).

Note: Although new to the Lazio region this West steno-Mediterranean species has been recorded in all Italian peri-Thyrrhenian regions, except for Campania [16].

Oloptum miliaceum (L.) Röser and H. R. Hamasha [三Agrostis miliaceum L.; $\equiv$ Oryzopsis miliacea (L.) Asch. and Schweinf.; झ Piptatherum miliaceum (L.) Coss.]

Poaceae Hemicryptophyte caespitose Mediterranean-Turanian

First records for Sardegna

Specimens: 2-6-2018, Sirigragiu, Corongiu (Maracalagonis, Cagliari province), reforestation with Eucaliptus, $84 \mathrm{~m}$ a.s.1., 9.2791 ${ }^{\circ}$ E-39.28434 ${ }^{\circ}$ N, leg. et det. E. Lallai (Herb. E. Lallai); 7-6-2018, C. D'Aquila, Stagno di Quartu (Quartu Sant'Elena, Cagliari province), olive grove, $3 \mathrm{~m}$ a.s.1., 9.17736 ${ }^{\circ}$ E-39.22613 ${ }^{\circ}$ N, leg. et det. E. Lallai (Herb. E. Lallai); 14-6-2018, Corti de Perda (Quartucciu, Cagliari province), reforestation with Eucaliptus and Pinus spp., $135 \mathrm{~m}$ a.s.1., $9.32868^{\circ}$ E-39.24517 $\mathrm{N}$, leg. et det. E. Lallai (Herb. E. Lallai).

Note: In the recent checklist of Italian vascular flora only $O$. thomasii and not O. miliaceum has been reported from Sardegna [16]. However, O. miliaceum is the only species that has ever been considered present in the flora treatments of Sardegna e.g., $[47,74,75]$. In addition, several authors consider questionable the distinction between these two taxa and include O. thomasii in O. milaceum. Our observations confirm the presence of $O$. miliaceum, accordingly this name has to be re-added to the checklist of vascular flora of Sardegna. O. miliaceum is present in almost all Italian regions except Valle d'Aosta, Piemonte e Molise [16].

Ophrys crabronifera Mauri [ $\equiv$ O. argolica H. Fleischm. ex Vierh. subsp. crabronifera (Mauri) Faurh.; = O. exaltata Ten. subsp. sundermannii Soó; $=$ O. fuciflora (F. W. Schmidt) Moench subsp. sundermannii Soó] Orchidaceae Geophyte bulbouse Italian endemic

First record for Basilicata

Observation: 15-4-2015; 30-4-2019, along the road SP 12 Vietrese (Vietri di Potenza, Potenza province), roadside on calcareous substratum, $371 \mathrm{~m}$ a.s.l., $40.57086^{\circ} \mathrm{N}-15.52102^{\circ} \mathrm{E}$, photo et det. V.A. Romano (Figure 2). 
Note: This species was previously recorded in almost all the peninsular regions except for Puglia, Calabria, and Basilicata. This observation extends southward the range of this endemic taxon in Italy [16]. It is absent in the insular regions [16].

Ophrys marmorata G. Foelsche and W. Foelsche [三 Ophrys fusca Link subsp. marmorata (G. Foelsche and W. Foelsche) Kreutz]

Orchidaceae Geophyte bulbouse Italian endemic

First record for Basilicata

Observation: 14-2-2015, Lido di Scanzano Jonico (Scanzano Jonico, Matera province), Pinus halepensis forest, $10 \mathrm{~m}$ a.s.l., $40.26114^{\circ} \mathrm{N}-16.75518^{\circ} \mathrm{E}$, photo et det. S. Fascetti et V.A. Romano (Figure 2).

Note: Since 2005, a few isolated flowering plants have been observed at this site flowering between February and March. The new findings extend southward the range of this endemic taxon in Italy; previously it had only been recorded from Toscana [16].

Ophrys sipontensis (Gumpr.) O. Danesch and E. Danesch [ $\equiv$ O. sphegodes Mill. subsp. sipontensis Gumpr.; $\equiv$ O. garganica O. Danesch and E. Danesch subsp. sipontensis (Gumpr.) Del Prete]

Orchidaceae G bulbouse Italian endemic

First record for Basilicata

Observation: 25-4-2015, Balvano (Potenza province), shrublands with Spartium junceum, $726 \mathrm{~m}$ a.s.l., $40.67352^{\circ} \mathrm{N}-15.52065^{\circ} \mathrm{E}$, photo et det. S. Fascetti et V.A. Romano (Figure 2).

Note: Since 2002, at this location only a few isolated flowering plants have been observed flowering between April and May. Hitherto this endemic orchid has only been recorded from Campania and Puglia regions [16].

Ophrys speculum Link [= O. ciliata Biv.]

Orchidaceae G bulbouse W-Steno-Mediterranean

Confirmation for Calabria

Observation: 15-4-2010, Frascineto (Cosenza province), roadside, $39.801091^{\circ} \mathrm{N}-16.241693^{\circ} \mathrm{E}, 420 \mathrm{~m}$ a.s.l., photo H. Presser, det. V.A. Romano (Figure 2).

Note: Previously reported from southern Italy only from Campania and Molise, it had otherwise been regarded as doubtfully present in Calabria [16].

Oxalis debilis Kunth [= O. corymbosa DC.]

Oxalidaceae G. bulbouse Neophyte, S-America

First record for Calabria (casual)

Specimens: 3-5-2019, Lazzaro (Motta San Giovanni, Reggio Calabria province), crevices in the road pavements, $17 \mathrm{~m}$ a.s.1., $37.97405^{\circ} \mathrm{N}-15.66492^{\circ} \mathrm{E}$, leg. et det. C.M. Musarella, conf. A. Stinca (PORUN-Herb. Stinca, REGGIO); 25-09-2019, Catona (Reggio Calabria, Reggio Calabria province), along the roadside, $15 \mathrm{~m}$ a.s.l., $38,189334^{\circ} \mathrm{N}-15,643462^{\circ}$ E, leg. V.L.A. Laface, det. V.L.A. Laface et C.M. Musarella conf. A. Stinca (PORUN-Herb. Stinca, REGGIO).

Note: At these locations only a few plants were recorded growing in the crevices and at the edge of the roadside; these probably escaped from plants cultivated in pots on the sidewalks. It is reported for several regions of Italy as a naturalized or casual alien [17]; it is considered doubtfully present in Lazio, Basilicata, and Puglia [17].

\section{Oxalis latifolia Kunth}

Oxalidaceae Geophyte bulbouse Neophyte, America

First record for Calabria (casual)

Specimens: 10-5-2018, Tortora Marina (Tortora, Cosenza province), fallows close to a plant nursery, 12 $\mathrm{m}$ a.s.1., $39.92276^{\circ} \mathrm{N}-15.76723^{\circ} \mathrm{E}$, leg. et det. S. Fascetti (HLUC); 29-7-2019, Catona (Reggio Calabria, Reggio Calabria province), sidewalks, $15 \mathrm{~m}$ a.s.l., $38.187390^{\circ} \mathrm{N}-15.643697^{\circ} \mathrm{E}$, leg. V.L.A. Laface, det. V.L.A. Laface, C.M. Musarella et G. Spampinato (REGGIO); 29-7-2019, Porelli di Bagnara SS18 (Bagnara Calabra, Reggio Calabria province), along the roadside, $142 \mathrm{~m}$ a.s.l., $38.286887^{\circ} \mathrm{N}-15.810304^{\circ} \mathrm{E}$, leg. 
V.L.A. Laface, det. V.L.A. Laface, C.M. Musarella et G. Spampinato conf. A. Stinca (PORUN-Herb. Stinca, REGGIO); 25-9-2019, Ferrito SS. 18 (Villa San Giovanni, Reggio Calabria province), along the roadside, $38 \mathrm{~m}$ a.s.1., $38.233512^{\circ} \mathrm{N}-15.660117^{\circ}$ E, leg. V.L.A. Laface, det. V.L.A. Laface, C.M. Musarella, G. Spampinato (REGGIO); 27.07.2019, Catona (Reggio Calabria, Reggio Calabria province), sidewalks, $10 \mathrm{~m}$ a.s.l., $38.188338^{\circ} \mathrm{N}-15.641358^{\circ}$ E, leg. V.L.A. Laface, det. V.L.A. Laface, C.M. Musarella et G. Spampinato conf. A. Stinca (PORUN-Herb. Stinca, REGGIO); 25.09.2019, Melia di Scilla (Melia di Scilla, Reggio Calabria province), $653 \mathrm{~m}$ a.s.l., $38.228695^{\circ} \mathrm{N}-15.757547^{\circ} \mathrm{E}$, leg. V.L.A. Laface, det. V.L.A. Laface, C.M. Musarella (REGGIO); 28.09.2019, Pietrastorta (Reggio Calabria, Reggio Calabria province), along the roadside, $317 \mathrm{~m}$ a.s.l., $38.113405^{\circ} \mathrm{N}-15.684027^{\circ} \mathrm{E}$, leg. et det. V.L.A. Laface (REGGIO); 21.10.2019, Molochio (Molochio, Reggio Calabria province), along the sidewalks, $316 \mathrm{~m}$ a.s.1., $38.310638^{\circ} \mathrm{N}-16.029284^{\circ}$ E, leg. et det. V.L.A. Laface (REGGIO).

Note: Abundantly naturalized. In some stations of Calabria, it probably escaped from plants grown in pots cultivated on the sidewalks as plants were seen in nearby crevices and on the nearby roadside. It was previously reported for almost all the Italian regions except for Molise, Basilicata, and Calabria in southern Italy [17]. In Basilicata region it is reported in the forum Acta Plantarum (2007 on-"Oxalis latifolia Kunth—Scheda IPFI, Acta Plantarum." Available on line (access date: 16/10/2019): http://www.actaplantarum.org/flora/flora_info.php?id=502806).

Paspalum notatum Flüggé [= P. saurae (Parodi) Parodi]

Poaceae Hemicryptophyte caespitose Neophyte, Central-S-America

First record for Basilicata (casual)

Specimen: 3-8-2017, Porto (Maratea, Potenza province), shores, $1 \mathrm{~m}$ a.s.1., $39.98927^{\circ} \mathrm{N}-15.70905^{\circ} \mathrm{E}$, leg. A. Stinca et M. Eviano. det. A. Stinca (PORUN-Herb. Stinca).

Note: Hitherto reported for Italy from the Calabria region as a casual alien at Scalea [77].

\section{Pedicularis petiolaris Ten.}

Orobanchaceae Hemicryptophyte scapose E-Mediterranean

Confirmation for Campania

Specimen: 27-5-2014, Mandranello (Padula, Salerno province), carbonatic dry grasslands, $1100 \mathrm{~m}$ a.s.l., $40.38762^{\circ} \mathrm{N}-15.68548^{\circ} \mathrm{E}$, leg. et det. L. Rosati (HLUC).

Note: In Italy it was previously reported only for Abruzzo, Basilicata, and Calabria regions [16]. In Campania it had previously only been considered doubtful present [16].

Pittosporum crassifolium Banks and Sol. ex A. Cunn.

Pittosporaceae Nano-phanerophyte Neophyte, New Zealand

First record for Italy (casual)

Specimen: 11-03-2013, Sardegna, Lungomare Valencia (Alghero, Sassari province), at back of disco bar near former castle, $9 \mathrm{~m}$ a.s.l., $40.55058^{\circ} \mathrm{N}-8.31974^{\circ} \mathrm{E}$, leg. et det. P.J. de Lange (AK)

Note: Associated with the superficially similar Pittosporum tobira (by far the most commonly grown and naturalized Pittosporum species in Sardegna). Pittosporum crassifolium was only seen here and at Torre Nuova (Alghero). Seedlings occasional, these appear to be pure Pittosporum crassifolium. In Europe it has previously recorded only from Great Britain [60].

\section{Phoenix canariensis H. Wildpret}

Arecaceae Phanerophyte scapose Neophyte, Macaronesia

First record for Basilicata (casual)

Specimens: 14-12-2017, S. Basilio, Marina di Pisticci (Pisticci, Matera province), roadside along Pinus halepensis forests, $5 \mathrm{~m}$ a.s.1., $40.29815^{\circ} \mathrm{N}-16.77887^{\circ} \mathrm{E}$, leg. et det. S. Fascetti (HLUC); 25-08-2019, Pisticci (Matera province), road escarpment of SS Jonica 106, 21 m a.s.l., $40.325447^{\circ} \mathrm{N}-16.746782^{\circ} \mathrm{E}$, leg. et det. C.M. Musarella (REGGIO).

Note: In loc. S. Basilio a few juvenile plants were observed probably spread from nearby gardens. In loc. Pisticci two mature individuals, away from each other about $50 \mathrm{~m}$, were recorded at the edge of a 
drainage channel along the SS Jonica 106, outside of a lay-by. Phoenix canariensis is reported as casual or naturalized for almost all coastal regions of peninsular Italy [17].

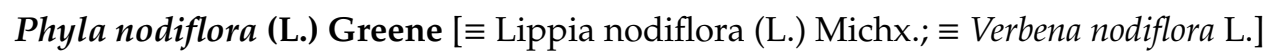

Verbenaceae Neophyte, Tropical America, Africa and Asia

Confirmation for Marche (casual)

Specimen: 3-8-2019, Osteria (Serra de' Conti, Ancona province), lawn borders and slopes of agricultural ditches for rainwater runoff, $135 \mathrm{~m}$ a.s.l., $43.541875^{\circ} \mathrm{N}-13.020947^{\circ} \mathrm{E}$, leg. et det. G. Mei (ANC, Herb. Mei). Note: Previously P. nodiflora was reported as naturalized from almost all the peninsular regions but it was considered as doubtfully present in Marche [17].

\section{Phyllostachys aurea Carrière ex Rivière and C. Rivière}

Poaceae Phanerophyte caespitose Neophyte, E-Asia

First record for Calabria (casual)

Specimens: 2-7-2019, Pellaro, Torrente Fiumarella (Reggio Calabria, Reggio Calabria province), dry riverbed, $6 \mathrm{~m}$ a.s.l., $38.02138^{\circ} \mathrm{N}-15.64416^{\circ} \mathrm{E}$, leg. et det. C.M. Musarella (REGGIO); 2-9-2019, C. da Monacelli, (Melicucco, Reggio Calabria province), roadside, $118 \mathrm{~m}$ a.s.l., $38.44528^{\circ} \mathrm{N}-16.04166^{\circ} \mathrm{E}$, leg. et det. C.M. Musarella (REGGIO); 9-8-2019, C. da Sant'Angelo (Melia di San Roberto, Reggio Calabria province), road escarpment, $749 \mathrm{~m}$ a.s.l., $38.22281^{\circ} \mathrm{N}-15.77548^{\circ} \mathrm{E}$, leg. V.L.A. Laface, det. V.L.A. Laface et G. Spampinato (REGGIO); 19.10.2019, Fiumara di S. Lorenzo (S. Lorenzo, Reggio Calabria province), bedriver, $6 \mathrm{~m}$ a.s.l., $37.920494^{\circ} \mathrm{N}-15.839534^{\circ} \mathrm{E}$, leg. et det. V.L.A. Laface (REGGIO).

Note: In southern Italy it was previously recorded only for Campania (naturalized) and Sicilia (casual) [17].

\section{Physalis peruviana $\mathbf{L}$.}

Solanaceae Hemicryptophyte scapose Neophyte, S-America

First record for Calabria (casual)

Specimen: 23-8-2019, Thurio (Corigliano Calabro, Cosenza province), fallows, $8 \mathrm{~m}$ a.s.1., 39.69515 N-16.46777, leg. P. Nicoletti, det. L. Rosati (HLUC).

Note: In southern Italy recorded previously only from Puglia and Sicilia regions [17].

Pinus nigra J. F. Arnold subsp. laricio Palib. ex Maire [= P. laricio Poir. subsp. calabrica (Loud.) Cesca and Peruzzi]

Pinaceae Phanerophyte scapose Italo-Corsican Endemic

First record for Basilicata (casual) and Campania (casual)

Specimens: 15-05-18, Mandrano, Monti della Maddalena (Paterno, Potenza province), pastures and roadsides, $1110 \mathrm{~m}$ a.s.l., $40.36917^{\circ} \mathrm{N}-15.71119^{\circ} \mathrm{E}$, leg. et det. L. Rosati (HLUC); 15-05-18, Mandrano, Monti della Maddalena (Padula, Salerno), pastures and roadsides $1075 \mathrm{~m}$ a.s.1., $40.36901^{\circ} \mathrm{N}-15.70758^{\circ}$ E, leg. et det. L. Rosati (HLUC).

Note: Several young trees from the nearby reforestation areas where this species had been deliberately planted were observed. It was recorded as alien taxa in others Italian regions (Sardegna, Fruli-Venezia Giulia, Toscana), whereas it is considered native only in Calabria and Sicilia [16].

\section{Plantago argentea Chaix subsp. argentea}

Plantaginaceae Hemicryptophyte rosulate S-European-S-Siberian

First record for Campania

Specimen: 20-7-2014, M. Alburno under M. Panormo (Sicignano degli Alburni, Salerno province), rocky slopes, $1402 \mathrm{~m}$ a.s.l., $40.53226^{\circ} \mathrm{N}-15.33386^{\circ}$ E, leg. A. Stinca et M. Ravo, det. A. Stinca (PORUN-Heb. Stinca).

Note: Plantago argentea was previously indicated in sensu lato in Campania, thus, here we report the presence of the nominal subspecies [16].

Plumbago auriculata Lam. [= Plumbago capensis Thunb.]

Plumbaginaceae Nano-phanerophyte Neophyte, S-Africa 
First record for Calabria (casual)

Specimen: 02-09-2019, C. da Monacelli (Melicucco, Reggio Calabria), roadside, $117 \mathrm{~m}$ a.s.l., $38.445020^{\circ}$ $\mathrm{N}-16.042060^{\circ} \mathrm{E}$, leg. et det. C. M. Musarella (REGGIO).

Note. In Calabria, we observed a few individuals growing along the roadside; these had probably escaped from a nearby garden. It is reported as casual alien from almost all the regions of Italian peninsula, except for Umbria, Molise, and Basilicata; in Sardegna it is considered naturalized [17].

\section{Polygala rupestris Pourr.}

Polygalaceae Chamaephyte subshrubs W-Mediterranean

First record for Sardegna and confirmation for Italy

Specimens: 02-11-2005; 14-05-2014; 08-04-2016, Canale Oma Molt (Alghero, Sassari province), garrigues with Rosmarinus officinalis and Viola arborescens, $33 \mathrm{~m}$ a.s.1., $40.52452^{\circ} \mathrm{N}-8.33371^{\circ} \mathrm{E}$, leg. et det. E. Farris (SS).

Note: In the recent checklist of the Italian vascular flora the presence of this species was considered doubtful in Italy [16]. We found this species in Sardegna along the coast South of Alghero, where it was usually present, though at low densities in the calcareous coastal garrigues. The nearest known localities of this species, according to Flora Gallica and Flora Iberica are in Provence (S-France) and Balearic Islands (Spain).

Populus $\times$ canescens (Aiton) Sm. [ $\equiv P$. alba L. var. canescens Aiton]

Salicaceae Phanerophyte scapose S-European

First record for Sardegna

Specimens: 21-6-2016, Settefratelli, along the road from Codoleddu to the giant's tombstone (Maracalagonis, Cagliari province), near the creek, $465 \mathrm{~m}$ a.s.1., $39.26022^{\circ} \mathrm{N}-9.37907^{\circ} \mathrm{E}$, leg. et det. L. Rosati (HLUC); 13-5-1981, Mandas (Mandas, Cagliari province), uscita dal paese verso Sorgono, $30 \mathrm{~m}$ a.s.1., $39.65376^{\circ}$ N-9.12843 ${ }^{\circ}$ E, leg. et det. I. Camarda (SS); 23-5-1975, Piana di Posada (Nuoro province), $5 \mathrm{~m}$ a.s.1., $40.635480^{\circ} \mathrm{N}-9.72371^{\circ} \mathrm{E}$, leg. S. Vanelli et B. Corrias (SS); 01-06-2018, Sedda Brandanu, Corongiu (Maracalagonis, Cagliari province), remnants of riparian forest, $140 \mathrm{~m}$ a.s.l., 39.29282 ${ }^{\circ} \mathrm{N}-9.29236^{\circ}$ E, leg. et det. E. Lallai (Herb. E. Lallai).

Note: In North Sardegna this species was also reported in a vegetation survey from the Cala Regina (Isola dell' Asinara, Sassari province) by [78]. In Italy it is widespread and known from all regions except for Liguria. This hybrid was reported for Sardegna by Camarda and Valsecchi [79] and Arrigoni [80] but not subsequently considered (by mistake?) in the recent checklist of vascular flora [16,74]. In the last checklist of the Italian vascular flora [16] it is not indicated as a hybrid (i.e. P. canescens (Aiton) Sm).

\section{Potamogeton pusillus L.}

Potamogetonaceae Idrophyte rooted Subcosmopolitan

Confirmation for Campania

Specimen: 16-7-2016, Sele river, Oasi Persano (Serre, Salerno province), lotic freshwaters, $40.60488^{\circ}$ $\mathrm{N}-15.13717^{\circ} \mathrm{E}$, leg. et det. L. Rosati et G. Salerno, rev. L. Lastrucci (HLUC).

Note: Outside Campania this species is not known from the southern Italian Peninsula [16]; it was recently confirmed from Basilicata [39].

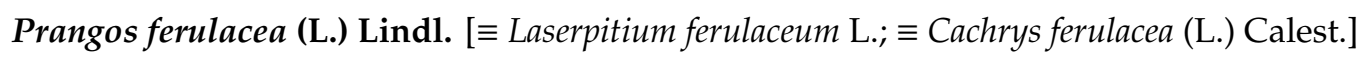

Apiaceae Hemicryptophyte scapose Mediterranean-Turanian

Confirmation for Lazio

Specimen: 16-7-2015, Monte Tilia, Fondo del Laghetto (Leonessa, Rieti province), secondary grasslands with Brachypodium genuense, marly slopes, $1400 \mathrm{~m}$ a.s.l., $42.55842^{\circ} \mathrm{N}-12.95441^{\circ} \mathrm{E}$, leg. et det. E. Del Vico (Herb. Del Vico).

Note: Doubtfully reported from Lazio on the basis of a historic record (1914) from Terminillo of Cavara and Grande which had not been confirmed by recent surveys [81]. On the basis of the record above 
Prangos ferulacea is now verified from the Lazio region. This species is, with the exception of Molise, otherwise known from the other regions of the Italian Peninsula [16].

Puccinellia festuciformis (Host) Parl. subsp. festuciformis [三 Poa festuciformis Host]

Poaceae Hemicryptophyte caespitose Steno-Mediterranean

Confirmation for Campania

Specimen: 12-6-2014, Patria lake, close to the dewatering pump (Giugliano in Campania, Napoli province), temporary flooded grasslands, $0 \mathrm{~m}$ a.s.l. $40.94181^{\circ} \mathrm{N}-14.0235^{\circ} \mathrm{E}$, leg. et det. A. Stinca et $\mathrm{G}$. Salerno (PORUN-Herb. Stinca).

Note: Until this discovery the presence of this grass in Campania had been considered doubtful [16]. Outside Campania this Puccinellia had been reported from several regions of the Italian Peninsula and considered as extinct in Abruzzo [16].

Quercus petraea (Matt.) Liebl. subsp. austrotyrrhenica Brullo, Guarino and Siracusa

Fagaceae Phanerophyte scapose Italian endemic

First record for Basilicata

Specimens: 15-6-2015, M.te Serranetta (Abriola, Potenza province), oak forests, $1300 \mathrm{~m}$ a.s.1., $40.56351^{\circ}$ $\mathrm{N}-15.81886^{\circ}$ E, leg. et det. S. Fascetti (HLUC); 15-8-2002, Serra di Calvello (Calvello, Potenza province), oak forests, $1300 \mathrm{~m}$ a.s.l., 40,45683 $\mathrm{N}-15,77855^{\circ} \mathrm{E}$, leg. et det. M.R. Lapenna (HLUC).

Note: This Italian endemic is uncommon in Basilicata, where it is generally found in mixed forests with Quercus cerris, in relatively xeric habitats on mountain ridges, exclusively on subacid substrata (e.g. Flysch Galestrino). Previously it was recorded only from Calabria and Sicilia regions [16].

Rosa $\times$ bishopii Wolley-Dod [= Rosa micrantha Borrer ex Sm. $\times$ R. agrestis Savi]

Rosaceae Nano-phanerophyte

First record for Basilicata

Specimen: 3-6-2011, Fiumara di Laurenzana (Laurenzana, Potenza province), shurbland in dry riverbed, 577 m s.l.m., $40.49004^{\circ} \mathrm{N}-15.9583^{\circ}$ E, leg. et det S. Fascetti, conf. E. Lattanzi (HLUC).

Note: Several hybrids into the wild dog roses group have been reported mainly in north-central Europe [82]; on the other hand, in southern Europe, knowledge concerning existence and distribution of these hybrids is very scarce. As a consequence, chorology for this taxon is not defined.

\section{Rosa montana Chaix $\times$ R. villosa $\mathrm{L}$.}

Rosaceae Nano-phanerophyte

First record for Basilicata

Specimen: 25-6-2016, Piano Jannace (San Severino Lucano, Potenza province), pastures, $1679 \mathrm{~m}$ a.s.l., 39.93977 $\mathrm{N}-16.19668^{\circ} \mathrm{E}$, leg. et det S. Fascetti, conf. E. Lattanzi (HLUC).

Note: Rosa villosa is one of the species of sect. Caninae DC. that can easily hybridize with other sympatric dog roses [83]. According to some authors, it is probably the most common hybridogenic species among the dog roses [84]. To the best of our knowledge, a binomial name for this hybrid does not exist yet. As a consequence, chorology for this taxon is not defined.

Rosa subcollina (Christ) Vuk. [ $\equiv$ R. coriifolia Fr. f. subcollina Christ]

Rosaceae Nano-phanerophyte European-W-Asian

First record for Basilicata

Specimen: 16-6-2011, Fossa Cupa (Pignola, Potenza province), shrublands, $1000 \mathrm{~m}$ a.s.1., 40.55197 $\mathrm{N}-15.73003^{\circ}$ E, leg. et det. S. Fascetti, rev. E. Lattanzi (HLUC).

Note: It is recorded from most of the Italian Peninsula regions.

\section{Rumex maritimus L.}

Polygonaceae Therophyte scapose Eurasian

First records for Campania

Specimens: 23-5-2014, near the harbour (Pozzuoli, Napoli province), sea sands, $0 \mathrm{~m}$ a.s.1., $40.82935^{\circ}$ N-14.11412 ${ }^{\circ}$ E, leg. et det. A. Stinca (PORUN-Herb. Stinca); 2-6-2014, Ponte del Diavolo on the banks of 
the Patria lake (Castel Volturno, Napoli province), artificial river bank, $1 \mathrm{~m}$ a.s.1., $40.92918^{\circ} \mathrm{N}-14.0287^{\circ}$ E, leg. A. Stinca et G. Salerno, det. A. Stinca (PORUN-Herb. Stinca); 3-6-2014, along the Canale Vico Patri close by Masseria De Chiara (Villa Literno, Napoli province), artificial river bank, $3 \mathrm{~m}$ a.s.1. $40.95818^{\circ} \mathrm{N}-14.04141^{\circ} \mathrm{E}$, leg. A. Stinca et G. Salerno, det. A. Stinca (PORUN-Herb. Stinca).

Note: Previously recorded only from Calabria in southern Italy [16].

\section{Salvinia minima Baker}

Salviniaceae Idrophyte floating Neophyte Central-S-America

First record for Europe (casual)

Specimen: 1-7-2019, Petile di Calanna (Calanna, Reggio Calabria province), impluvium, $38.19045^{\circ}$ N-15.73117 E, leg. V.L.A. Laface, det. V.L.A. Laface et C. M. Musarella (REGGIO).

Note: Salvinia minima is a non-rooted aquatic fern native to South and Central America. Madeira et al. [85] report this species as locally introduced for Spain, citing Lawarlee in Flora Europaea [42]. However, S. minima is not considered in Flora Europaea, neither in Flora Iberica [86]. For this reason, it may be that this record for Calabria is not the first for Italy but also for Europe. In this context, a case of accidentally introduction of Salvinia minima in Europe has been only documented in the botanical garden greenhouses in Jibou, Romania [87]. Detailed images of plants collected in Calabria are shown in Figure A2. The collected plants were identified using [88-91]; diacritical characters useful to distinguish S. minima with respect to the most similar taxa are shown in Table A2.
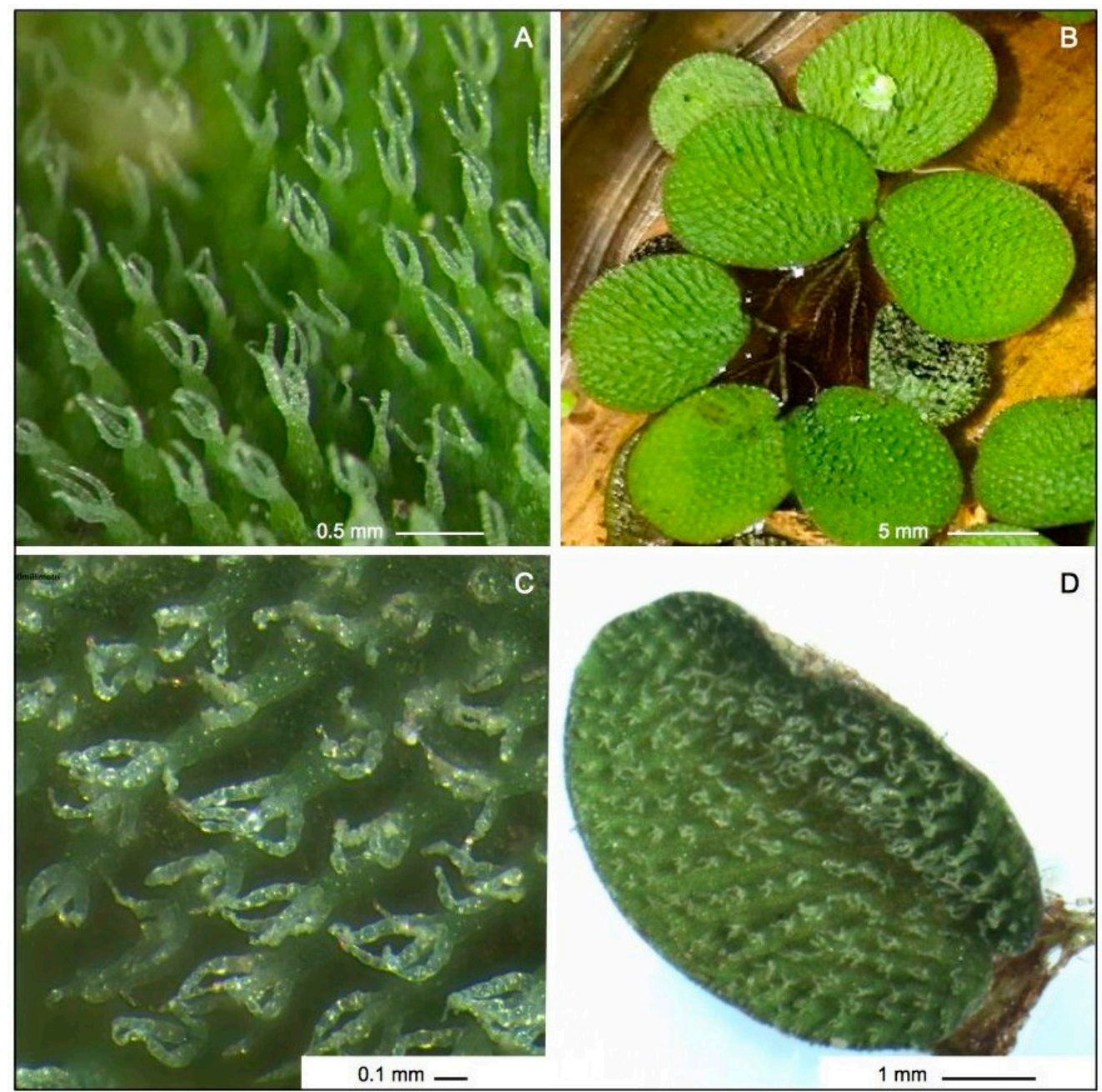

Figure A2. Salvinia minima plants collected in Calabria and photographed in laboratory at the University of Reggio Calabria: (A,C,D) upper side leaf hairs at different magnification, note distinctive hairs not joined at their tips (B) entire plants with the typical rounded leaves shape. 
Table A2. Distinguishing characters between Salvinia minima and the most similar species (data retrieved from [91] including measures taken on our samples collected in Calabria.

\begin{tabular}{ccccc}
\hline & $\begin{array}{c}\text { Floating Blade } \\
\text { Length }(\mathbf{m m})\end{array}$ & Hairs on Papillae & $\begin{array}{c}\text { Length/Width } \\
\text { Ratio }\end{array}$ & $\begin{array}{c}\text { Papillae on Upper } \\
\text { Face }(\mathbf{m m})\end{array}$ \\
\hline $\begin{array}{c}\text { S. adnata Desv. }(= \\
\begin{array}{c}\text { S. molesta } \\
\text { D. S. Mitch.) }\end{array}\end{array}$ & $15-25$ & $\begin{array}{c}\text { Joined into dark } \\
\text { knot at tips }\end{array}$ & $<1.5$ & $<0.1$ \\
\hline S. oblongifolia Mart. & $25-45$ & $\begin{array}{c}\text { Not joined at } \\
\text { their tips }\end{array}$ & $2-3$ & $\leq 1$ \\
\hline S. minima Baker & $5-10(15)$ & $\begin{array}{c}\text { Not joined at } \\
\text { their tips }\end{array}$ & $<1.5$ & $\leq 1$ \\
\hline
\end{tabular}

\section{Sempervivum tectorum $\mathrm{L}$.}

\section{Crassulaceae Chamaephyte S-European}

First record for Basilicata

Specimen: 15-6-2019, M. Volturino (Marsico Vetere, Potenza province), siliceous rocks and cliffs, 1500 $\mathrm{m}$ a.s.l., $40.4026^{\circ} \mathrm{N}-15.81642^{\circ} \mathrm{E}$, leg. L. Rosati et G. Potenza, det. L. Rosati (HLUC).

Note: Present in central and northern regions of Italy but in southern regions, records of it from Puglia, Basilicata, and Calabria have been treated as mistakes [16]. Therefore, the discovery of Mt. Volturino reported here now confirms its presence in the southern Apennine.

Solandra maxima (Sessé and Moc.) P. S. Green [三 Datura maxima Sessé and Moc.]

Solanaceae Phanerophyte climbing Neophyte, Central America

First record for Calabria (casual) and Sicilia (casual)

Specimen: 9-8-2019, Ferrito (Villa San Giovanni, Reggio Calabria province), roadside, $34 \mathrm{~m}$ a.s.l., $38.23229^{\circ} \mathrm{N}-15.64493^{\circ}$ E, leg. V.L.A. Laface, det. V.L.A. Laface, C.M. Musarella et G. Spampinato (REGGIO); 5-7-2019, Canalicchio (Catania), road escarpment, $91 \mathrm{~m}$ a.s.l., $37.53119^{\circ} \mathrm{N}-15.09410^{\circ} \mathrm{E}$, leg. C.M. Musarella, det. C.M. Musarella et G. Spampinato (REGGIO).

Note: Solandra maxima was recorded for the first time in Europe from the Campania region [92]. Our two records are therefore the second for the Italian peninsula and the first for Calabria and Sicilia respectively.

\section{Tagetes erecta L. [= T. patula L.]}

Asteraceae Therophyte scapose Neophyte, Central American

First record for Basilicata (casual)

Specimen: 3-8-2017, Porto (Maratea, Potenza province), crevices in road pavements, $16 \mathrm{~m}$ a.s.l., $39.98889^{\circ} \mathrm{N}-15.70958^{\circ} \mathrm{E}$, leg. A. Stinca et M. Eviano. det. A. Stinca (PORUN-Herb. Stinca).

Note: This species has been recorded as casual alien from many Italian regions [17].

Tetragonia tetragonoides (Pall.) Kuntze [三 Demidovia tetragonoides Pall.]

Aizoaceae Therophyte scapose Neophyte, Australia and New Zealand

Confirmation for Sardegna (casual)

Specimen: 19-05-2013, Golfo di Orosei, Cala Gonone (Orosei, Nuoro province), cobble beach, $1 \mathrm{~m}$ a.s.l., $40.28270^{\circ} \mathrm{N}-9.63620^{\circ} \mathrm{E}$, leg. et det. P.J. de Lange (AK).

Note: Flowering and fruiting plants have been observed (see https://inaturalist.nz/observations/1509928). In Italy it was previously reported in Friuli Venezia Giulia, Trentino-Alto Adige, Lombardia, Toscana, Lazio, Campania, and Sicilia regions [17]. Prior to this record this species was known from Sardegna on the basis of old reports that required confirmation [17]. 
Trifolium spumosum L.

Fabaceae Therophyte scapose E-Steno-Mediterranean

Confirmation for Basilicata

Specimen: 16-6-2014, Anglona Sanctuary (Tursi, Matera province), dry grassland, $262 \mathrm{~m}$ a.s.1., 40.2449

N-16.55653 E, leg. G. Salerno et M.R. Lapenna, det. G. Salerno (Herb. Salerno).

Note: The presence of this species in Italy was ascertained only from Sardegna, Sicilia, Calabria, and Lazio [16]. In recent times this species has not been recorded from most of the Italian peninsular regions [16]. Our discovery from Basilicata confirms its continued presence from at least part of that region.

Urginea fugax (Moris) Steinh. [三 Anthericum fugax Moris]

Asparagaceae Geophyte bulbouse W-Mediterranean

Exclusion for continental and peninsular Italy (Basilicata)

Note: In Italy, we can only confirm this species as present in Sardegna [16], which is consistent with its W-Mediterranean distribution. Accordingly, we regard past records of the species from Basilicata and neighboring regions as erroneous. Although Gavioli [51] reported the species from Basilicata in 1915 the samples he noted had been lost, so the record cannot be verified. In absence of further specimens of this distinctive plant from the Italian Peninsula we suggest that $U$. fugax had probably been reported by mistake, because of the confusion with a similar species (likely small size individuals of Urginea maritima auct. Fl. Ital.). Therefore, we recommend that this species is excluded from the flora of Basilicata.

Veronica spicata L. subsp. fischeri (Trávn.) Albach [झ Pseudolysimachion spicatum (L.) Opiz subsp. fischeri Trávn]

Plantaginaceae Hemicryptophyte crawling Eurasian

First records for Lazio

Specimens: 2-7-2015, Monte Rosato (Poggio Bustone, Rieti province), secondary grassland with Bromopsis erecta, Carex humilis and Plantago argentea, calcareous slopes, $1300 \mathrm{~m}$ a.s.l., $42.51662^{\circ}$

N-12.88791 ${ }^{\circ}$ E, leg. et det. E. Del Vico (Herb. Del Vico); 10-7-2016, Monte Rosato (Poggio Bustone, Rieti province), secondary grassland with Bromopsis erecta, calcareous slopes, $1350 \mathrm{~m}$ a.s.1., $42.51387^{\circ}$ N-12.88557 E, leg. E. Del Vico et L. Facioni det. E. Del Vico (Herb. Del Vico).

Note: In Italy this taxon has a northern (Lombardia, Trentino-Alto Adige, Veneto) and central (Marche, Umbria, Abruzzo) disjunct distribution [16]. In Piemonte it is recorded by mistake [16]. Subspecies identification of our samples was based on the key reported in [20]; however, in our view the subspecies delimitation of $V$. spicata as stated in [20] is unclear and needs further study.

Viola kitaibeliana Schult.

Violaceae Therophyte scapose European-Caucasian

Confirmation for Campania

Specimen: 1-3-2016, Campitello, M. della Maddalena (Padula, Salerno province), pastures on siliceous schistous substrate, $1300 \mathrm{~m}$ a.s.l., $40.34573^{\circ} \mathrm{N}-15.69029^{\circ} \mathrm{E}$, leg. et det. L. Rosati (HLUC).

Note: Viola kitaibeliana is recorded from most of the peninsular regions, except for Emilia-Romagna, Molise, and Puglia; it was previously considered as doubtfully present in Campania [16]. Our discovery now fills this gap along the Apennine chain.

Wisteria sinensis (Sims) Sweet [三 Glycine sinensis Sims]

Fabaceae Phanerophyte climbing Neophyte, E-Asia

First record for Calabria (casual)

Specimen: 2-9-2019, C. da Monacelli (Melicucco, Reggio Calabria province), roadside, $118 \mathrm{~m}$ a.s.l., $38.44528^{\circ} \mathrm{N}-16.04166^{\circ}$ E, leg. et det. C.M. Musarella (REGGIO).

Note: A few individuals of Wisteria sinensis were noted growing together with Phyllostachys aurea and Plumbago auriculata along the roadside, probably escaped from a nearby garden. Previously Wisteria 
sinensis was recorded as casual alien from almost all of the Italian regions but only from Campania in the southern ones [17]. In Sardegna it is considered naturalized [17].

\section{References}

1. Crisafulli, A.; Cannavò, S.; Maiorca, G.; Musarella, C.M.; Signorino, G.; Spampinato, G. Aggiornamenti floristici per la Calabria. Informatore Botanico Italiano 2010, 42, 431-442.

2. Rosati, L.; Romano, V.A.; Bartolucci, F.; Bernardo, L.; Bouvet, D.; Cancellieri, L.; Caruso, G.; Conti, F.; Faraoni, F.; Banfi, E.; et al. Contribution to the floristic knowledge of the Maddalena Mountains (Basilicata and Campania, southern Italy). Ital. Bot. 2017, 3, 73-82. [CrossRef]

3. Farris, E.; Carta, M.; Circosta, S.; Falchi, S.; Papuga, G.; de Lange, P. The indigenous vascular flora of the forest domain of Anela (Sardinia, Italy). PhytoKeys 2018, 113, 97-143. [CrossRef] [PubMed]

4. Bartolucci, F.; Cancellieri, L.; Conti, F.; Banfi, E.; Bouvet, D.; Celestini, M.; Ciaschetti, G.; Di Pietro, R.; Falcinelli, F.; Fascetti, S.; et al. Contribution to the floristic knowledge of Velino and Aterno valleys (Lazio-Abruzzo, central Italy). Ital. Bot. 2019, 7, 93-100. [CrossRef]

5. Conti, F.; Ciaschetti, G.; Di Martino, L.; Bartolucci, F. An annotated checklist of the vascular flora of Majella, National Park (Central Italy). Phytotaxa 2019, 412, 1-90. [CrossRef]

6. Conti, F.; Falcinelli, F.; Giacanelli, V.; Paolucci, M.; Pirone, G.; Proietti, E.; Stinca, A.; Bartolucci, F. New floristic data of vascular plants from central and southern Italy. Flora Mediterranea 2019, 29, 215-222.

7. Motti, R.; Esposito, A.; Stinca, A. New additions to the exotic vascular flora of Campania (southern Italy). Annali di Botanica 2018, 8, 75-85.

8. Stinca, A. The Genus Vitis L. (Vitaceae) in Campania (southern Italy), with emphasis on alien units. Annali di Botanica 2019, 9, 107-112.

9. Stinca, A.; Ravo, M.; Giacanelli, V.; Conti, F. Integrazioni alla flora vascolare dell'Isola di Capri. Atti Della Società Toscana di Scienze Naturali Residente in Pisa Memorie serie B 2016, 123, $65-70$.

10. Stinca, A.; Chianese, G.; D'Auria, G.; Del Guacchio, E.; Fascetti, S.; Perrino, E.V.; Rosati, L.; Salerno, G.; Santangelo, A. New alien vascular species for the flora of southern Italy. Webbia 2017, 72, 295-301. [CrossRef]

11. Stinca, A.; Ravo, M.; Giacanelli, V.; Conti, F. Additions to the vascular flora of the islands of Procida and Vivara (Campania, southern Italy). Atti Della Società Toscana di Scienze Naturali Residente in Pisa Memorie Serie B 2018, 125, 87-93.

12. Stinca, A.; Chianese, G.; D’Auria, G.; Fascetti, S.; Ravo, M.; Romano, V.A.; Salerno, G.; Astuti, G.; Bartolucci, F.; Bernardo, L.; et al. Contribution to the floristic knowledge of eastern Irpinia and Vulture-Melfese area (Campania and Basilicata, southern Italy). Ital. Bot. 2019, 8, 1-16. [CrossRef]

13. Musarella, C.M. Solanum torvum Sw. (Solanaceae): A new alien species for Europe. Gen. Resour. Crop Evolut. 2019. [CrossRef]

14. Musarella, C.M.; Stinca, A.; Cano-Ortíz, A.; Laface, V.L.A.; Petrilli, R.; Esposito, A.; Spampinato, G. New data on the alien vascular flora of Calabria (southern Italy). Annali di Botanica. in press. [CrossRef]

15. Musarella, C.M.; Tripodi, G. La flora della rupe e dei ruderi di Pentidattilo (Reggio Calabria). Inform. Bot. Ital. 2004, 36, 3-12.

16. Bartolucci, F.; Peruzzi, L.; Galasso, G.; Albano, A.; Alessandrini, A.; Ardenghi, N.M.G.; Astuti, G.; Bacchetta, G.; Ballelli, S.; Banfi, E.; et al. An updated checklist of the vascular flora native to Italy. Plant Biosyst. 2018, 152, 179-303. [CrossRef]

17. Galasso, G.; Conti, F.; Peruzzi, L.; Ardenghi, N.M.G.; Banfi, E.; Celesti-Grapow, L.; Albano, A.; Alessandrini, A.; Bacchetta, G.; Ballelli, S.; et al. An updated checklist of the vascular flora alien to Italy. Plant Biosyst. Int. J. Deal. All Asp. Plant Biol. 2018, 152, 556-592. [CrossRef]

18. Pignatti, S. Flora d'Italia: In 4 Volumi. Volume 1: Flora d'Italia \& Flora Digitale, 2nd ed.; Edagricole-Edizioni Agricole di New Business Media srl: Milano, Italy, 2017; ISBN 978-88-506-5242-6.

19. Pignatti, S. Flora d'Italia: In 4 Volumi. Volume 2: Flora d'Italia \& Flora Digitale, 2nd ed.; Edagricole-Edizioni Agricole di New Business Media srl: Milano, Italy, 2017; ISBN 978-88-506-5243-3.

20. Pignatti, S. Flora d'Italia: In 4 Volumi. Volume 3: Flora d'Italia \& Flora Digitale, 2nd ed.; Edagricole-Edizioni Agricole di New Business Media srl: Milano, Italy, 2018; ISBN 978-88-506-5244-0.

21. Pignatti, S.; Guarino, R.; La Rosa, M. Flora d'Italia: In 4 Volumi. Volume 3: Flora d'Italia \& Flora Digitale, 2nd ed.; Edagricole-Edizioni Agricole di New Business Media srl: Milano, Italy, 2019; ISBN 978-88-506-5242-6. 
22. Musarella, C.M.; Mendoza-Fernández, A.J.; Mota, J.F.; Alessandrini, A.; Bacchetta, G.; Brullo, S.; Caldarella, O.; Ciaschetti, G.; Conti, F.; Di Martino, L.; et al. Checklist of gypsophilous vascular flora in Italy. PhytoKeys 2018, 103, 61-82. [CrossRef]

23. Marignani, M.; Bacchetta, G.; Bagella, S.; Caria, M.C.; Delogu, F.; Farris, E.; Fenu, G.; Filigheddu, R.; Blasi, C. Is time on our side? Strengthening the link between field efforts and conservation needs. Biodivers. Conserv. 2014, 23, 421-431. [CrossRef]

24. Bini, L.M.; Diniz-Filho, J.A.F.; Rangel, T.F.L.V.B.; Bastos, R.P.; Pinto, M.P. Challenging Wallacean and Linnean shortfalls: Knowledge gradients and conservation planning in a biodiversity hotspot. Divers. Distrib. 2006, 12, 475-482. [CrossRef]

25. Hortal, J.; de Bello, F.; Diniz-Filho, J.A.F.; Lewinsohn, T.M.; Lobo, J.M.; Ladle, R.J. Seven Shortfalls that Beset Large-Scale Knowledge of Biodiversity. Ann. Rev. Ecol. Evolut. Syst. 2015, 46, 523-549. [CrossRef]

26. Rosati, L.; Coppi, A.; Farris, E.; Fascetti, S.; Becca, G.; Peregrym, M.; Tan, K.; Selvi, F. The genus Gymnospermium (Berberidaceae) in Italy: Identity and relationships of the populations at the western limit of the genus range. Plant Biosyst. 2019, 153, 796-808. [CrossRef]

27. Rosati, L.; Romano, V.A.; Cerone, L.; Fascetti, S.; Potenza, G.; Bazzato, E.; Cillo, D.; Mecca, M.; Racioppi, R.; D'Auria, M.; et al. Pollination features and floral volatiles of Gymnospermium scipetarum (Berberidaceae). J. Plant Res. 2019, 132, 49-56. [CrossRef]

28. Sala, O.E. Global Biodiversity Scenarios for the Year 2100. Science 2000, 287, 1770-1774. [CrossRef]

29. Weber, E. Invasive Plant Species of the World: A Reference Guide to Environmental Weeds, 2nd ed.; CABI: Wallingford, Oxfordshire, UK; Boston, MA, USA, 2016; ISBN 978-1-78064-386-1.

30. Médail, F. The specific vulnerability of plant biodiversity and vegetation on Mediterranean islands in the face of global change. Reg. Environ. Chang. 2017, 17, 1775-1790. [CrossRef]

31. Roy, H.E.; Bacher, S.; Essl, F.; Adriaens, T.; Aldridge, D.C.; Bishop, J.D.D.; Blackburn, T.M.; Branquart, E.; Brodie, J.; Carboneras, C.; et al. Developing a list of invasive alien species likely to threaten biodiversity and ecosystems in the European Union. Glob. Chang. Biol. 2018, 25, 1032-1048. [CrossRef]

32. Index Herbariorum: A Global Directory of Public Herbaria; Thiers, B. New York Botanical Garden's Virtual Herbarium. Available online: http://sweetgum.nybg.org/ih/ (accessed on 25 May 2019).

33. Bartolucci, F.; Domina, G.; Ardenghi, N.M.G.; Banfi, E.; Bernardo, L.; Bonari, G.; Buccomino, G.; Calvia, G.; Carruggio, F.; Cavallaro, V.; et al. Notulae to the Italian native vascular flora: 5. Ital. Bot. 2018, 5, 71-81. [CrossRef]

34. Bartolucci, F.; Domina, G.; Ardenghi, N.M.G.; Bacchetta, G.; Bernardo, L.; Buccomino, G.; Buono, S.; Caldararo, F.; Calvia, G.; Carruggio, F.; et al. Notulae to the Italian native vascular flora: 6. Ital. Bot. 2018, 6, 45-64. [CrossRef]

35. Bartolucci, F.; Domina, G.; Alessandrini, A.; Angiolini, C.; Ardenghi, N.M.G.; Bacchetta, G.; Banfi, E.; Bolpagni, R.; Bonari, G.; Bräuchler, C.; et al. Notulae to the Italian native vascular flora: 7. Ital. Bot. 2019, 7, 125-148. [CrossRef]

36. Galasso, G.; Domina, G.; Adorni, M.; Ardenghi, N.M.G.; Bonari, G.; Buono, S.; Cancellieri, L.; Chianese, G.; Ferretti, G.; Fiaschi, T.; et al. Notulae to the Italian alien vascular flora: 5. Ital. Bot. 2018, 5, 45-56. [CrossRef]

37. Galasso, G.; Domina, G.; Alessandrini, A.; Ardenghi, N.M.G.; Bacchetta, G.; Ballelli, S.; Bartolucci, F.; Brundu, G.; Buono, S.; Busnardo, G.; et al. Notulae to the Italian alien vascular flora: 6. Ital. Bot. 2018, 6, 65-90. [CrossRef]

38. Galasso, G.; Domina, G.; Ardenghi, N.M.G.; Aristarchi, C.; Bacchetta, G.; Bartolucci, F.; Bonari, G.; Bouvet, D.; Brundu, G.; Buono, S.; et al. Notulae to the Italian alien vascular flora: 7. Ital. Bot. 2019, 7, 157-182. [CrossRef]

39. Bartolucci, F.; Domina, G.; Ardenghi, N.M.G.; Bacaro, G.; Bacchetta, G.; Ballarin, F.; Banfi, E.; Barberis, G.; Beccarisi, L.; Bernardo, L.; et al. Notulae to the Italian native vascular flora: 8. Ital. Bot. 2019, 8, 95-116. [CrossRef]

40. Galasso, G.; Domina, G.; Andreatta, S.; Angiolini, C.; Ardenghi, N.M.G.; Aristarchi, C.; Arnoul, M.; Azzella, M.M.; Bacchetta, G.; Bartolucci, F.; et al. Notulae to the Italian alien vascular flora: 8. Ital. Bot. 2019, 8, 63-93. [CrossRef]

41. WFO: World Flora Online. Published on the Internet. Available online: http://www.worldfloraonline.org (accessed on 20 December 2019).

42. Tutin, T.G. Flora Europaea, 2nd ed.; Cambridge University Press: Cambridge, UK, 1993; ISBN 978-0-521-41007-6. 
43. Tutin, T.G. Flora Europaea: Rosaceae to Umbelliferae. In Flora Europaea; Cambridge University Press: Cambridge, UK, 2001; ISBN 978-0-521-06662-4.

44. Tutin, T.G. Flora Europaea: Diapensiaceae to Myoporaceae; Cambridge University Press: Cambridge, UK, 2007; ISBN 978-0-521-08489-5.

45. Tutin, T.G. Flora Europaea: Plantaginaceae to Compositae (and Rubiaceae); Cambridge University Press: Cambridge, UK, 2006; ISBN 978-0-521-08717-9.

46. Tutin, T.G. Flora Europaea: Alismataceae to Orchidaceae (Monocotyledones); paperback printing; Cambridge University Press: Cambridge, UK, 2010; ISBN 978-0-521-20108-7.

47. Pignatti, S. Flora d'Italia; 1-3; Edagricole: Bologna, Italy, 1982.

48. Pyšek, P.; Richardson, D.M.; Rejmánek, M.; Webster, G.L.; Williamson, M.; Kirschner, J. Alien plants in checklists and floras: Towards better communication between taxonomists and ecologists. Taxon 2004, 53, 131-143. [CrossRef]

49. Schmid, E. Beitrage zur Flora der Insel Sardinien. Vierteljahrsschrift der Naturforschenden Gesellschaft in Zürich 1933, 78, 249.

50. Mossa, L.; Curreli, F.; Fogu, M.C. La vegetazione degli habitat terrestri della riserva marina protetta di Capo Carbonara (Sardegna sud-orientale). Rendiconti del Seminario della Facoltà di Scienze dell'Università di Cagliari 2000, 70, 163-185.

51. Gavioli, O. Synopsis Florae Lucanae. Nuovo Giornale Botanico Italiano (nuova serie) 1948, 54, 134-135. [CrossRef]

52. Rosenbaum, G.; Lister, G.S.; Duboz, C. Reconstruction of the tectonic evolution of the western Mediterranean since the Oligocene. J. Virtual Explor. 2002, 8, 107-130. [CrossRef]

53. Speranza, F.; Villa, I.M.; Sagnotti, L.; Florindo, F.; Cosentino, D.; Cipollari, P.; Mattei, M. Age of the Corsica-Sardinian rotation and Liguro-Provencal Basin spreading: New pale-omagnetic and Ar/Ar evidence. Tectonophysics 2002, 347, 231-251. [CrossRef]

54. Grill, A.; Casula, P.; Lecis, R.; Menken, S. Endemism in Sardinia. In Phylogeography of Southern European Refugia; Springer: Dordrecht, The Netherlands, 2007.

55. Jacono, C.C.; Davern, T.R.; Center, T.D. The adventive status of Salvinia minima and S. molesta in the Southern United States and the related distribution of the weevil Cyrtobagous salviniae. Castanea 2001, 66, 214-226.

56. Španiel, S.; Marhold, K.; Passalacqua, N.G.; Zozomová-Lihová, J. Intricate variation patterns in the diploid-polyploid complex of Alyssum montanum-A. repens (Brassicaceae) in the Apennine Peninsula: Evidence for long-term persistence and diversification. Am. J. Bot. 2011, 98, 1887-1904. [CrossRef]

57. Ballero, M.; Cara, S.; Marras, G.; Loi, M.C. La flora del Fluminese (Sardegna sud-occidentale). Webbia 2000, 55, 65-105. [CrossRef]

58. Koch, M.A.; Karl, R.; German, D.A. Underexplored biodiversity of Eastern Mediterranean biota: Systematics and evolutionary history of the genus Aubrieta (Brassicaceae). Ann. Bot. 2017, 119, 39-57. [CrossRef]

59. Fascetti, S.; Navazio, G.; Silletti, G. Aggiornamento delle conoscenze floristiche della Basilicata: Conferma di antiche segnalazioni e nuovi dati distributivi di specie rare. Inform. Bot. Ital. 2004, 36, 425-428.

60. Zieritz, A.; Armas, B.; Aldridge, D.C. Registry of non-native species in the Two Seas region countries (Great Britain, France, Belgium and the Netherlands). NeoBiota 2014, 23, 65-80.

61. De Lange, P.J. Coprosma repens Fact Sheet (Content Continuously Updated). New Zealand Plant Conservation Network, 2019. Available online: http://www.nzpcn.org.nz/flora_details.aspx?ID=1730 (accessed on 20 December 2019).

62. Beever, R.E.; Parkes, S.L. Self-incompatibility in Cordyline australis (Asteliaceae). N. Z. J. Bot. 1996, 34, $135-137$. [CrossRef]

63. Papuga, G.; Filigheddu, R.; Gauthier, P.; Farris, E. Variation in floral morphology in a hybrid complex of Cyclamen in Sardinia. Plant Ecol. Divers. 2019, 12, 51-61. [CrossRef]

64. Thompson, J.D.; Gauthier, P.; Papuga, G.; Pons, V.; Debussche, M.; Farris, E. The conservation significance of natural hybridisation in Mediterranean plants: From a case study on Cyclamen (Primulaceae) to a general perspective. Plant Biol. 2018, 20, 128-138. [CrossRef]

65. Raven, P.H.; Raven-Engelhorn, T. The Genus Epilobium (Onagraceae) in Australasica: A Systematic and Evolutionary Study; New Zealand Department of Scientific and Industrial Research Bulletin 216; New Zealand Department of Scientific and Industrial Research Government Printer: Wellington, New Zealand, 1976; p. 321. 
66. De Lange, P.J. Epilobium brunnescens subsp. brunnescens Fact Sheet (Content Continuously Updated). New Zealand Plant Conservation Network, 2019. Available online: http://www.nzpcn.org.nz/flora_details.aspx? ID=1839 (accessed on 30 December 2019).

67. De Lange, P.J. Epilobium komarovianum Fact Sheet (Content Continuously Updated). New Zealand Plant Conservation Network, 2019. Available online: http://www.nzpcn.org.nz/flora_details.aspx?ID=1850 (accessed on 30 December 2019).

68. De Lange, P.J. Epilobium nummularifolium Fact Sheet (Content Continuously Updated). New Zealand Plant Conservation Network, 2019. Available online: http://www.nzpcn.org.nz/flora_details.aspx?ID=1857 (accessed on 30 December 2019).

69. Turner, B.L. Texas Species of Glandularia (Verbenaceae). Lundellia 1998, 1, 3-16. [CrossRef]

70. O'Leary, N.; Thode, V. The Genus Glandularia (Verbenaceae) in Brazil. Ann. Mo. Bot. Gard. 2016, 101, 699-749. [CrossRef]

71. Thode, V.A.; Bordignon, S.A.D.L. Two new species of Glandularia (Verbenaceae) from Rio Grande do Sul and an updated key to the species occurring in Brazil. Phytotaxa 2019, 411, 39-48. [CrossRef]

72. Tison, J.-M.; Foucault, B.; de, Guiol, F. Flora Gallica: Flore de France; Biotope Éditions: Mèze, France, 2014; ISBN 978-2-36662-012-2.

73. Arrigoni, P.V. Flora Dell'isola di Sardegna 3; Società botanica italiana; Carlo Delfino: Sassari, Italy, 2010; ISBN 978-88-7138-414-6.

74. Conti, F.; Abbate, G.; Alessandrini, A.; Blasi, C. An Annotated Checklist of Italian Vascular Flora; Palombi Editore: Roma, Italy, 2005.

75. Arrigoni, P.V. Flora Dell'isola di Sardegna 6; Società botanica italiana; Carlo Delfino: Sassari, Italy, 2015; ISBN 978-88-7138-414-6.

76. DAISIE-Inventory of Alien Invasive Species in Europe. Version 1.6. Research Institute for Nature and Forest (INBO). Checklist Dataset. Available online: https://doi.org/10.15468/ybwd3x (accessed on 21 September 2019).

77. Stinca, A.; Galasso, G.; Banfi, E. First Italian record of Paspalum notatum Flüggé (Poaceae) and its typification. Acta Bot. Croat. 2016, 75, 153-156. [CrossRef]

78. Pisanu, S.; Farris, E.; Caria, M.C.; Filigheddu, R.; Urbani, M.; Bagella, S. Vegetation and plant landscape of Asinara National Park (Italy). Plant Sociol. 2014, 51, 31-57.

79. Camarda, I.; Valsecchi, F. Alberi e Arbusti Della Sardegna; Carlo Delfino: Sassari, Italy, 2008.

80. Arrigoni, P.V. Flora dell'isola di Sardegna 1; Società botanica italiana; Carlo Delfino: Sassari, Italy, 2006; ISBN 978-88-7138-414-6.

81. Anzalone, B.; Iberite, M.; Lattanzi, E. La flora vascolare del Lazio. Inf. Bot. Ital. 2010, 42, 187-317.

82. Ritz, C.M.; Wissemann, V. Male correlated non-matroclinal character inheritance in reciprocal hybrids of Rosa section Caninae (DC.) Ser. (Rosaceae). Plant Syst. Evolut. 2003, 241, 213-221. [CrossRef]

83. Schanzer, I.A.; Kutlunina, N.A. Interspecific hybridization in wild roses (Rosa L. sect. Caninae DC.). Biol. Bull. 2010, 37, 480-488. [CrossRef]

84. Nybon, H.; Nilsson, U.C.; Werlemark, G.; Uggla, M. Different levels of morphometric variation in three heterogamous dogroses species. Plant. Syst. Evol. 1997, 204, 207-224. [CrossRef]

85. Madeira, P.T.; Jacono, C.C.; Tipping, P.; Van, T.K.; Center, T.D. A genetic survey of Salvinia minima in the southern United States. Aquat. Bot. 2003, 76, 127-139. [CrossRef]

86. Castroviejo, S. Flora iberica, Lycopodiaceae-Papaveraceae; Real Jardín Botánico de Madrid: Madrid, Spain, 1998; ISBN 978-84-00-06222-4.

87. Szatmari, P.-M.; Căprar, M. Research on spontaneous and subspontaneous flora of Botanical Garden "Vasile Fati" Jibou. J. Hortic. For. Biotechnol. 2015, 19, 176-189.

88. Riefner, R.E., Jr.; Smith, A.R. Salvinia minima and S. oblongifolia (Salviniaceae) new to California, with notes on the S. auriculata complex. J. Bot. Res. Inst. Tex. 2009, 3, 855-866.

89. Mikulyuk, A.; Nault, M.E. Water Spangles (Salvinia minima): A Technical Review of Distribution, Ecology, Impacts, and Management; Wisconsin Department of Natural Resources Bureau of Science Services, PUB-SS-1053 2009; U.S. Fish \& Wildlife Service: Madison, WI, USA, 2009.

90. Flora of North America. Available online: http://www.efloras.org/florataxon.aspx?flora_id=1\&taxon_id= 233501216 (accessed on 20 November 2019). 
91. Jepson Flora Project. 2019. Jepson eFlora. Available online: http://ucjeps.berkeley.edu/eflora/ (accessed on 31 December 2019).

92. Salerno, G.; Stinca, A. First European record of Solandra maxima (Sessè \& Moc.) P. S. Green (Solanaceae). Annali di Botanica 2017, 7, 1-4.

(c)

(C) 2020 by the authors. Licensee MDPI, Basel, Switzerland. This article is an open access article distributed under the terms and conditions of the Creative Commons Attribution (CC BY) license (http://creativecommons.org/licenses/by/4.0/). 